\title{
Ventral Tegmental Area Dopamine Cell Activation during Male Rat Sexual Behavior Regulates Neuroplasticity and D-Amphetamine Cross-Sensitization following Sex Abstinence
}

\author{
Lauren N. Beloate, ${ }^{1,2}{ }^{\circledR}$ Azar Omrani, ${ }^{4}$ Roger A. Adan, ${ }^{4}$ Ian C. Webb, ${ }^{1}$ and ${ }^{\odot L i q u e ~ M . ~ C o o l e n ~}{ }^{1,3}$ \\ ${ }^{1}$ Department of Neurobiology and Anatomical Sciences, ${ }^{2}$ Graduate Program in Neuroscience, and ${ }^{3}$ Department of Physiology and Biophysics, University of \\ Mississippi Medical Center, Jackson, Mississippi 39216, and ${ }^{4}$ Brain Center Rudolf Magnus, Department of Translational Neuroscience, University Medical \\ Center Utrecht, 3584 CG Utrecht, The Netherlands
}

Experience with sexual behavior causes cross-sensitization of amphetamine reward, an effect dependent on a period of sexual reward abstinence. We previously showed that $\Delta \mathrm{FosB}$ in the nucleus accumbens $(\mathrm{NAc})$ is a key mediator of this cross-sensitization, potentially via dopamine receptor activation. However, the role of mesolimbic dopamine for sexual behavior or cross-sensitization between natural and drug reward is unknown. This was tested using inhibitory designer receptors exclusively activated by designer drugs in ventral tegmental area (VTA) dopamine cells. rAAV5/hSvn-DIO-hm4D-mCherry was injected into the VTA of TH::Cre adult male rats. Males received clozapine $\mathrm{N}$-oxide ( $\mathrm{CNO}$ ) or vehicle injections before each of 5 consecutive days of mating or handling. Following an abstinence period of $7 \mathrm{~d}$, males were tested for amphetamine conditioned place preference (CPP). Next, males were injected with CNO or vehicle before mating or handling for analysis of mating-induced $\mathrm{cFos}$, sex experience-induced $\Delta \mathrm{FosB}$, and reduction of VTA dopamine soma size. Results showed that CNO did not affect mating behavior. Instead, CNO prevented sexual experience-induced cross-sensitization of amphetamine CPP, $\triangle$ FosB in the NAc and medial prefrontal cortex, and decreases in VTA dopamine soma size. Expression of hm4DmCherry was specific to VTA dopamine cells and CNO blocked excitation and mating-induced cFos expression in VTA dopamine cells. These findings provide direct evidence that VTA dopamine activation is not required for initiation or performance of sexual behavior. Instead, VTA dopamine directly contributes to increased vulnerability for drug use following loss of natural reward by causing neuroplasticity in the mesolimbic pathway during the natural reward experience.

Key words: FosB; mesolimbic; nucleus accumbens; prefrontal cortex; psychostimulant; reward

Significance Statement

Drugs of abuse act on the neural pathways that mediate natural reward learning and memory. Exposure to natural reward behaviors can alter subsequent drug-related reward. Specifically, experience with sexual behavior, followed by a period of abstinence from sexual behavior, causes increased reward for amphetamine in male rats. This study demonstrates that activation of ventral tegmental area dopamine neurons during sexual experience regulates cross-sensitization of amphetamine reward. Finally, ventral tegmental area dopamine cell activation is essential for experience-induced neural adaptations in the nucleus accumbens, prefrontal cortex, and ventral tegmental area. These findings demonstrate a role of mesolimbic dopamine in the interaction between natural and drug rewards, and identify mesolimbic dopamine as a key mediator of changes in vulnerability for drug use after loss of natural reward.

\section{Introduction}

Drugs of abuse act on the mesolimbic circuit, which mediates natural reward behavior and memory (Frohmader et al., 2010;
Olsen, 2011; Pitchers et al., 2013, 2014). There is increasing recognition that experience with natural and social reward behaviors influence drug-related behavior and development of addiction

\footnotetext{
Received March 21, 2016; revised Aug. 9, 2016; accepted Aug. 10, 2016.

Author contributions: L.N.B., A.O., R.A.A., I.C.W., and L.M.C. designed research; L.N.B. and A.O. performed research; L.N.B., A.O., R.A.A., and L.M.C. analyzed data; L.N.B., A.O., R.A.A., I.C.W., and L.M.C. wrote the paper.

The authors declare no competing financial interests.
}

Correspondence should be addressed to Dr. Lique M. Coolen, Department of Physiology and Biophysics, University of Mississippi Medical Center, 2500 North State Street, Jackson, MS 39216. E-mail: Icoolen@umc.edu. DOI:10.1523/JNEUROSCI.0937-16.2016

Copyright $\odot 2016$ the authors $\quad 0270-6474 / 16 / 369949-13 \$ 15.00 / 0$ 
(Heilig et al., 2016). For example, stress and social isolation (Lu et al., 2003; Nader et al., 2012; Koob et al., 2014) and exposure to fat (Kenny, 2011) increase vulnerability to drug-seeking behavior in rodent preclinical studies. In contrast, exposure to an enriched environment (Thiel et al., 2009; Solinas et al., 2010; Gipson et al., 2011) and pair bonding in voles (Aragona et al., 2007; Liu et al., 2011) have protective effects against susceptibility to drugs of abuse. In recent years, the neurobiological basis for the interaction between natural and drug reward has been demonstrated by our laboratory for sexual behavior and the psychostimulant D-amphetamine, in male rats. During sexual behavior, $\mu$ opioid receptors (MORs) in the ventral tegmental area (VTA) are activated, resulting in activation of dopamine neurons (Balfour et al., 2004) and dopamine release in the nucleus accumbens (NAc; Pfaus et al., 1990; Damsma et al., 1992; Di Chiara, 1999; Fiorino and Phillips, 1999). Antagonism of MORs in the VTA during the acquisition of sexual experience disrupts the long-term expression of sexual reward memory, without affecting sexual motivation, performance, or reward (Pitchers et al., 2014). Moreover, activation of VTA MORs and dopamine cells occurs upon exposure to contextual conditioned cues predictive of sexual reward (Balfour et al., 2004; Pitchers et al., 2014) and, in turn, mediates cue-induced neural activity in VTA projection areas (Pitchers et al., 2014). Such findings are in agreement with the general role of dopamine in reward-related learning (Wise, 2002; Everitt and Robbins, 2005; Kalivas and Volkow, 2005; Fields et al., 2007; Brom et al., 2014; Stauffer et al., 2016) and encoding of the predictive salience of reward-associated cues (Schultz, 2013; Steinberg et al., 2013; Stauffer et al., 2016). However, the role of VTA dopamine activation in sexual behavior remains unclear. Antagonism of D1 dopamine receptors in the NAc did not affect sexual behavior, but the study was limited to a single dose (Pitchers et al., 2013). Moreover, VTA dopamine may influence sex behavior by acting in other mesolimbic areas.

Sexual experience causes cross-sensitization of amphetamineinduced locomotor activity and conditioned place preference (CPP; Pitchers et al., 2010a, 2013, 2016; Beloate et al., 2016). Importantly, the cross-sensitizing effects of sexual experience on amphetamine reward are dependent on a period of sexual abstinence (Pitchers et al., 2010a, 2013), and a key mediator of this amphetamine cross-sensitization is mating-induced $\Delta$ FosB expression in the NAc (Pitchers et al., 2010b, 2013). In turn, $\Delta$ FosB is regulated by NAc D1 (Pitchers et al., 2013) and NMDA receptor activation (Beloate et al., 2016), suggesting roles for dopamine and/or glutamate in the cross-sensitizing effects of loss of sexual reward. Sexual experience also causes a decrease in dopamine soma size in the VTA, via mating-induced activation of MOR (Pitchers et al., 2014). However it is unknown whether sex experience-induced plasticity is dependent on dopamine neuron activity during mating behavior.

Together, these results suggest that dopamine cell activation in the VTA is not essential for the initiation or expression of sexual behavior, but regulates sex experience-induced neural plasticity in the mesolimbic pathway and amphetamine reward cross-sensitization. The current study directly tested this hypothesis using designer receptors exclusively activated by designer drugs (DREADDs; Lee et al., 2014) and male rats that express Cre recombinase under the control of the tyrosine hydroxylase promotor (TH::Cre; Witten et al., 2011) for selective manipulation of VTA dopamine cell activation during the acquisition of sexual experience.

\section{Materials and Methods}

Animals

All rats were housed in same-sex pairs in standard Plexiglas cages. Food and water were provided ad libitum, and animals were maintained in temperature-controlled and humidity-controlled rooms on a $12 \mathrm{~h}$ dark/ light cycle. All experiments were performed in accordance with the U.S. National Institutes of Health guidelines involving vertebrate animals in research and in agreement with Dutch laws (Wet op Dierproeven 1996) and European regulations (Guideline 86/609/EEC), and were approved by the Institutional Animal Care and Use Committee at the University of Mississippi Medical Center or the Animal Ethics Committee of Utrecht University.

TH::Cre males. Heterozygous transgenic male rats expressing Cre recombinase under the control of the tyrosine hydroxylase (TH) promotor (TH::Cre) were bred from TH::Cre males (National Institutes of Health Rat Resource and Research Center, Columbia, MO; Long-Evans background; RRID:RGD_10401201; Witten et al., 2011; Pandit et al., 2016) and wild-type Long-Evans females (Charles River). Offspring genotyping was done via PCR using DNA isolated from tail biopsies with REDExtract-N-Amp PCR Ready mix (Sigma-Aldrich; catalog \#R4775; $10 \mu \mathrm{l})$ in $4 \mu \mathrm{l}$ of double-distilled water $\left(\mathrm{ddH}_{2} \mathrm{O}\right)$ supplemented with 10 $\mu \mathrm{M}$ forward and reverse primers ( $1 \mu \mathrm{l}$ of each primer): $5^{\prime}$-CGT TCA CCG GCA TCA ACG TTT-3'; 5'-GCG GCA TGG TGC AAG TTG AAT-3' (Integrated DNA Technologies). PCR reaction conditions consisted of 1 cycle of $94^{\circ} \mathrm{C}$ for $3 \mathrm{~min} ; 35$ cycles of $94^{\circ} \mathrm{C}$ for $1 \mathrm{~min}, 60.8^{\circ} \mathrm{C}$ for $1 \mathrm{~min}$, and $72^{\circ} \mathrm{C}$ for $1 \mathrm{~min}$; and $1 \mathrm{cycle}$ of $72^{\circ} \mathrm{C}$ for $10 \mathrm{~min}$. PCR products were separated by electrophoresis on a $1 \%$ agarose gel in $1 \times$ TAE buffer (BioRad Laboratories; catalog \#161-0743) to visualize the 232 bp product indicative of Cre recombinase.

Females. Female Sprague Dawley rats (Charles River; 201-225 g; RRID:RGD_734476) used for mating behavior tests were bilaterally ovariectomized and implanted with subcutaneous capsules (Dow Corning tubing; $1.98 \mathrm{~mm}$ internal diameter) containing 5\% 17- $\beta$-estradiolbenzoate (in cholesterol; $1 \mathrm{~cm}$ filled area). Females received $500 \mu \mathrm{g}$ of progesterone in $0.1 \mathrm{ml}$ of sesame oil (Sigma-Aldrich; subcutaneous) 3-6 $\mathrm{h}$ before each mating session to induce sexual receptivity.

\section{Behavioral studies}

Viral-mediated transfection of DREADD receptors. A chemogenetic approach was used to specifically inhibit VTA dopamine neurons. TH::Cre males received bilateral VTA microinjections of a recombinant adenoassociated virus (rAAV) encoding a Cre-driven $\mathrm{G}_{\mathrm{i}}$-coupled DREADD (rAAV5/hSyn-DIO-hm4D-mCherry; University of North Carolina Vector Core, Chapel Hill, NC). Animals were deeply anesthetized with ketamine $(87 \mathrm{mg} / \mathrm{ml} / \mathrm{kg}) / x y l a z i n e ~(13 \mathrm{mg} / \mathrm{ml} / \mathrm{kg}$, i.p.) and placed into a stereotaxic apparatus (Kopf Instruments). Skulls were exposed, and burr holes were drilled to target the VTA. rAAV vectors were injected at a volume of $1 \mu \mathrm{l} /$ injection using a $10 \mu \mathrm{l}$ Hamilton syringe (Harvard Apparatus) attached to a microdrive (Kopf Instruments, model 5000). For the behavioral studies, $\mathrm{TH}:: \mathrm{Cre}$ rats were $8-16$ weeks old at time of injection and all animals received two injections per hemisphere at two rostrocaudal locations as follows: anteroposterior (AP) $-5.0 \mathrm{~mm}$ and AP $-5.8 \mathrm{~mm}$, mediolateral (ML) $\pm 0.7 \mathrm{~mm}$ from bregma, and dorsoventral (DV) $-8.4 \mathrm{~mm}$ from skull. For ex vivo electrophysiology experiments TH::Cre rats were injected with the virus at 5-7 weeks old, using one injection of $1 \mu \mathrm{l} / \mathrm{hemisphere}$ at AP $-4.8 \mathrm{~mm}, \mathrm{ML} \pm 1.0 \mathrm{~mm}$ from bregma, and DV $-7.1 \mathrm{~mm}$ from skull ( $5^{\circ}$ angle). Each infusion was slowly delivered over $2 \mathrm{~min}$, and the needle was left in place for an additional $5 \mathrm{~min}$. Animals received $5 \mathrm{mg} / \mathrm{ml} / \mathrm{kg}$ carprofen (subcutaneous) during surgery and $24 \mathrm{~h}$ later for analgesia, and were allowed a 3 week recovery before onset of experiments.

Chemogenetic inhibition of VTA dopamine cells during mating. TH::Cre transgenic males expressing Cre-driven $G_{i}$ DREADDs received either mating sessions (sexually experienced) or control handling (sexually naive) over 5 consecutive days. Forty minutes before each session, the animals were administered clozapine $\mathrm{N}$-oxide (CNO; $1 \mathrm{mg} / \mathrm{ml} / \mathrm{kg}$ dissolved in saline, s.c.; Tocris Bioscience) or the vehicle control saline $(1 \mathrm{ml} / \mathrm{kg}$, s.c.). The dose of $\mathrm{CNO}$ was chosen based on previous behavioral studies 
using hM4Di manipulations (Robinson et al., 2014; Jennings et al., 2015).

For sexual behavior testing, males were placed in a mating arena $(60 \times$ $45 \times 50 \mathrm{~cm}$ ) with clean bedding for $5 \mathrm{~min}$, after which they mated with a receptive female until one ejaculation. If males did not reach ejaculation, tests were terminated $1 \mathrm{~h}$ after introduction of the female. Males assigned to the sexually naive group were placed in identical test cages with clean bedding for $30 \mathrm{~min}$, but did not receive sexually receptive females. Naive males were housed and handled in the same rooms as the sexually experienced males and thus subjected to identical environmental conditions. All testing took place 3-6 h after lights off, under dim red lighting, and were videotaped.

The following mating parameters were calculated for sexually experienced animals: latencies to first anogenital investigation and numbers of anogenital investigations during the first $2 \mathrm{~min}$, first mount (time from introduction of female to first mount), intromission (time from introduction of female to first intromission), and ejaculation (time from first intromission to ejaculation); copulation efficiency [number of intromissions/(number of mounts + intromissions)]; and percentages of animals displaying mounts, intromissions, and ejaculations. Parameters were compared between drug-treatment groups and between mating sessions with a repeated-measures two-way ANOVA using 95\% confidence levels. Animals were included in analyses only for sexual parameters that they displayed for each of the sessions. Percentages of animals displaying each behavior were compared between groups for each mating session using $\chi^{2}$ analysis.

Amphetamine CPP testing. One week after the last mating or handling session, all animals were subjected to CPP for amphetamine, as previously described (Pitchers et al., 2010a; Frohmader et al., 2011; Beloate et al., 2016). The CPP apparatus consists of two main chambers separated by a smaller middle chamber, each distinguishable by visual and tactile cues (Med Associates). Testing occurred over 4 d. On day 1, a 15 min pretest was conducted, in which males were allowed to freely roam the CPP apparatus. On days 2 and 3, animals were administered D-amphetamine hemisulfate salt (Sigma-Aldrich; product \#A5880; 0.5 $\mathrm{mg} / \mathrm{ml} / \mathrm{kg}$ calculated on the basis of the free base, s.c.) and confined to one chamber of the apparatus for $30 \mathrm{~min}$, or were administered vehicle (saline) and confined to the other chamber for $30 \mathrm{~min}$. The order of treatments was counterbalanced, and the design was unbiased (half of the animals had amphetamine paired with the initially preferred chamber and half with the initially nonpreferred chamber). At this dose, sexually experienced rats develop a CPP while naive rats do not (Pitchers et al., 2010a, 2013; Beloate et al., 2016). On day 4 the change in preference was determined during a post-test procedurally identical to the pretest.

The CPP score (difference in time spent in the amphetamine-paired chamber during the post-test minus the pretest) was calculated for each animal. Animals were excluded from analysis if they displayed an initial preference of $\geq 120 \mathrm{~s}$ for one of the three chambers ( $n=1$ in each group) or a CPP score $>3$ SDs from the average of the group $(n=1$ in each group). CPP scores were compared between groups and analyzed using a one-way ANOVA on ranks followed by Dunn's post hoc analysis. Salinepretreated and CNO-pretreated sexually naive groups were not statistically different and were combined for this analysis. For all tests, 95\% confidence levels were used.

\section{Tissue processing}

Tissue collection. Five days following CPP testing, the effects of inhibiting VTA dopamine neurons on mating-induced cFos expression were examined. $\mathrm{CNO}(1 \mathrm{mg} / \mathrm{ml} / \mathrm{kg}$ dissolved in saline, s.c. $)$ or saline $(1 \mathrm{ml} / \mathrm{kg}$, s.c. $)$ was administered $30 \mathrm{~min}$ before mating to one ejaculation or handling, using the same group designation as during the initial stage of the experiment (sexually experienced, mating; sexually naïve, no mating). All animals received an overdose of sodium pentobarbital (Vortech Pharmaceutical; $390 \mathrm{mg} / \mathrm{ml} / \mathrm{kg}$, i.p.) $1 \mathrm{~h}$ after the initiation of mating and were transcardially perfused with $10 \mathrm{ml}$ saline $[0.9 \% \mathrm{NaCl}$ (SigmaAldrich) in $\mathrm{ddH}_{2} \mathrm{O}$ ] and $500 \mathrm{ml}$ of $4 \%$ paraformaldehyde [Electron Microscopy Sciences; in $0.1 \mathrm{~m}$ phosphate buffer (PB)]. Brains were removed and postfixed for $1 \mathrm{~h}$ in the same fixative at room temperature and stored in a sucrose solution [Thermo Fisher Scientific; $20 \%$ in $0.1 \mathrm{M}$ PB containing $0.01 \%$ sodium azide (Sigma-Aldrich)] at $4^{\circ} \mathrm{C}$.

Immunohistochemistry. Using a freezing stage microtome (SM 2000R, Leica Biosystems), brains were sectioned coronally (35 $\mu \mathrm{m})$ into four parallel series and stored in $-20^{\circ} \mathrm{C}$ in cryoprotectant solution $[30 \% \mathrm{su}-$ crose in $0.1 \mathrm{~m} \mathrm{~PB}$ containing 30\% ethylene glycol (Thermo Fisher Scientific) and $0.01 \%$ sodium azide] until processing. For all staining procedures detailed below, free-floating sections were incubated and washed at room temperature under gentle agitation, thoroughly washed in PBS, pH 7.4, between all incubations, and exposed to $1 \% \mathrm{H}_{2} \mathrm{O}_{2}(10$ min; in PBS) and antibody incubation solution [1 h; PBS containing $0.1 \%$ bovine serum albumin (Thermo Fisher Scientific) and $0.4 \%$ Triton X-100 (Sigma-Aldrich)]. Sections were mounted onto Superfrost plus glass slides (Fisher Laboratories) and coverslipped with gelvatol containing antifading agent 1,4-diazabicyclo(2,2)octane (Sigma-Aldrich; 50 mg/ $\mathrm{ml}$; for all immunofluorescence detection) or dehydrated and coverslipped with dibutyl phthalate xylene (Electron Microscopy Sciences; for chromogen detection). For each of the staining procedures, sections of all animals were processed simultaneously.

$m$ Cherry and TH. One series of sections per animal containing VTA was incubated in mouse anti-TH (EMD Millipore, catalog \#MAB5280; RRID: AB_2201526; 1:1000; 17 h), Dylight 488-conjugated goat anti-mouse (Thermo Fisher Scientific, catalog \#SA-35503; RRID:AB_1965946; 1:100 in PBS; 30 min), rabbit anti-mCherry (Abcam, catalog \#ab167453; RRID: AB_2571870; 1:40,000; $17 \mathrm{~h}$ ), and Alexa 555-conjugated goat anti-rabbit (Invitrogen, catalog \#A21428; RRID:AB_141784; 1:100 in PBS; 30 min). The antibody for TH has been previously used and validated (Balfour et al., 2004; Baltazar et al., 2013; Pitchers et al., 2014), and mCherry immunostaining was validated to be $100 \%$ colocalized with the endogenous mCherry expressed by the viral construct in a separate series of sections.

cFos and TH. One series of sections containing VTA was incubated with rabbit anti-cFos (Santa Cruz Biotechnology, catalog sc-52; RRID: AB_2106783; 17 h), biotinylated goat anti-rabbit (Vector Laboratories, catalog \#BA-1000; RRID:AB_2313606; 1:500; 1 h), avidin-biotin-horseradish peroxidase (ABC Elite; Vector Laboratories, catalog \#PK-6100; RRID: AB_2336819; 1:1000 in PBS; 1 h), and 0.02\% 3,3'-diaminobenzidine tetrahydrochloride (DAB; Sigma-Aldrich) with $0.02 \%$ nickel sulfate (SigmaAldrich) and $0.015 \% \mathrm{H}_{2} \mathrm{O}_{2}$ in $0.1 \mathrm{M} \mathrm{PB}(10 \mathrm{~min})$. Next, sections were incubated in a mouse anti-TH (Millipore, catalog \#MAB5280; 1:800,000; $17 \mathrm{~h}$ ), biotinylated goat anti-mouse (Vector Laboratories, catalog \#BA-9200; RRID:AB_2336171; 1:500; $1 \mathrm{~h}$ ), ABC Elite (Vector; 1:1000 in PBS; $1 \mathrm{~h}$ ), and $0.02 \%$ DAB (Sigma-Aldrich) with $0.015 \% \mathrm{H}_{2} \mathrm{O}_{2}$ in $0.1 \mathrm{M} \mathrm{PB}$ (10 min). The cFos antibody has been previously validated to specifically recognize cFos (Pitchers et al., 2010b; Beloate et al., 2016).

cFos. One series of sections containing VTA projection areas were incubated in rabbit anti-cFos (Santa Cruz Biotechnology, catalog \#sc-52; $17 \mathrm{~h}$ ), biotinylated goat anti-rabbit (Vector Laboratories, catalog \#BA-1000; 1:500; $1 \mathrm{~h}$ ), avidin-biotin-horseradish peroxidase (ABC Elite; Vector Laboratories, catalog \#PK-6100; 1:1000 in PBS; $1 \mathrm{~h}$ ), and 0.02\% DAB (Sigma-Aldrich) with $0.02 \%$ nickel sulfate (Sigma-Aldrich) and $0.015 \% \mathrm{H}_{2} \mathrm{O}_{2}$ in $0.1 \mathrm{M} \mathrm{PB}(10$ $\min )$.

$\Delta$ FosB. One series of sections containing VTA projection areas were incubated in a rabbit polyclonal antibody raised against an internal region shared by FosB and $\Delta$ FosB (pan-FosB; Santa Cruz Biotechnology, catalog \#sc-48; RRID:AB_631515; 1:5000; 17 h), biotinylated goat antirabbit IgG (Vector Laboratories; 1:500; $1 \mathrm{~h}$ ), ABC Elite (Vector Laboratories; $1: 1000$ in PBS; $1 \mathrm{~h}$ ), and $0.02 \%$ DAB (Sigma-Aldrich) with $0.02 \%$ nickel sulfate (Sigma-Aldrich) and $0.015 \% \mathrm{H}_{2} \mathrm{O}_{2}$ in $0.1 \mathrm{M} \mathrm{PB}(10 \mathrm{~min})$. The FosB antibody has been previously validated to specifically visualize $\Delta$ FosB under these conditions (Perrotti et al., 2004, 2008; Pitchers et al., 2010a,b, 2013).

\section{Tissue analyses}

DREADD expression. Sections fluorescently stained for $\mathrm{TH}$ and $\mathrm{mCherry}$ were examined and the location of mCherry expression was mapped throughout the rostral-to-caudal and medial-to-lateral extent of the VTA. All animals had sufficient spread throughout the VTA and none were excluded from the analyses. For a representative subpopulation of animals $(n=10)$, images of rostral-caudal levels of VTA were taken at 
$10 \times$ magnification, and numbers of $\mathrm{TH}+, \mathrm{mCherry}+$, and $\mathrm{TH}+$ / mCherry \pm cells were quantified in the medial $(400 \times 300 \mu \mathrm{m})$ and lateral $(500 \times 600 \mu \mathrm{m})$ subregions of the VTA using Neurolucida (MBF Bioscience; RRID:SCR_004314).

Mating-induced cFos expression in the VTA. Numbers of TH,$+ \mathrm{cFos}+$, and $c$ Fos $+/ \mathrm{TH}+$ cells were quantified in medial and lateral VTA subregions at three rostrocaudal levels ( -4.56 to $-6.00 \mathrm{~mm}$ from bregma) using a bright-field microscope (Leica DMR; Leica Microsystems) with a camera lucida phototube attachment at $10 \times$ magnification. The VTA subregions were based on the findings of Fu et al. (2012) and the rostrocaudal levels were based on the findings of Balfour et al. (2004). The medial subregions analyzed included the rostral linear nucleus (RLi), interfascicular nucleus (IF), and caudal linear nucleus of raphe (CLi; all $200 \times 600 \mu \mathrm{m}$ area of analysis), and the lateral subregions included the rostral, middle, and caudal parabrachial pigmented nucleus (PBP; $1000 \times 800 \mu \mathrm{m}$ area of analysis). All counts were averaged per animal, per area of analysis, and compared between groups using a two-way ANOVA (sexually experienced vs naïve; $\mathrm{CNO}$ vs vehicle) and HolmSidak pairwise comparisons, all with $p<0.05$ for significance.

Mating-induced cFos and experience-induced $\Delta F o s B$ in VTA projection areas. cFos-immunoreactive or FosB-immunoreactive cells were quantified using a bright-field microscope with drawing tube attachment (Leica DMR; Leica Microsystems). The areas analyzed included the NAc shell and core $(400 \times 600 \mu \mathrm{m}$ per subregion); the anterior cingulate area (ACA); the infralimbic (IL) and prelimbic (PL) subareas $(600 \times 800 \mu \mathrm{m}$ per subregion) of the medial prefrontal cortex (mPFC); and the basolateral amygdala (BLA; $400 \times 300 \mu \mathrm{m})$. Two-to-three sections per animal were counted and the counts were averaged per animal, per area of analysis. All measures were compared between groups using a two-way ANOVA (sexually experienced vs naïve; $\mathrm{CNO}$ vs vehicle) and HolmSidak pairwise comparisons, all with $p<0.05$ for significance.

Morphological analysis of VTA dopamine cells. Images of THimmunoreactive neurons in the lateral PBP subregion at the middle level $(-5.28 \mathrm{~mm}$ to $-5.64 \mathrm{~mm}$ from bregma) VTA were taken at $40 \times$ magnification from tissue processed for $\mathrm{TH}$ and cFos. The soma size was analyzed using ImageJ (National Institutes of Health). Mean area and perimeter were measured as described in Pitchers et al. (2014). An average of $\geq 20$ cells per animal was analyzed and only cells with a clearly visible nucleus were included. For each animal, the mean area and perimeter were calculated. Measures were compared between groups using a two-way ANOVA (sexually experienced vs naïve; $\mathrm{CNO}$ vs vehicle) and Holm-Sidak pairwise comparisons, all with $p<0.05$ for significance.

\section{Electrophysiological studies}

Horizontal slices of the midbrain $(300 \mu \mathrm{m})$ were prepared from $T H:: C r e$ rats injected with rAAV5/hSyn-DIO-hm4D-mCherry (University of North Carolina Vector Core, Chapel Hill, NC) as described above and by Pandit et al. (2016), using a vibratome (Leica VT1200S, Leica Microsystems) in ice-cold modified artificial CSF (ACSF) containing the following (in mM): $92 \mathrm{~N}$-methyl-D-glucamine, $2.5 \mathrm{KCl}, 1.25 \mathrm{NaH}_{2} \mathrm{PO}_{4}, 30$ $\mathrm{NaHCO}_{3}, 20$ HEPES, 25 glucose, 2 thiourea, $5 \mathrm{Na}$-ascorbate, 3 napyruvate, $0.5 \mathrm{CaCl}_{2} \cdot 4 \mathrm{H}_{2} \mathrm{O}$, and $10 \mathrm{MgSO}_{4} \cdot 7 \mathrm{H}_{2} \mathrm{O}$, bubbled with $95 \% \mathrm{O}_{2}$ and $5 \% \mathrm{CO}_{2}, \mathrm{pH}$ 7.3-7.4. Slices were initially recovered in carbogenated modified ACSF for $15 \mathrm{~min}$ at $34^{\circ} \mathrm{C}$ and then transferred into a holding chamber with standard ACSF [containing as follows (in $\mathrm{mM}$ ): $126 \mathrm{NaCl}$, $3 \mathrm{KCl}, 2 \mathrm{MgSO}_{4}, 2 \mathrm{CaCl}_{2}, 10$ glucose, $1.25 \mathrm{NaH}_{2} \mathrm{PO}_{4}$, and $26 \mathrm{NaHCO}_{3}$ ) bubbled with $95 \% \mathrm{O}_{2}$ and $5 \% \mathrm{CO}_{2}, \mathrm{pH} 7.3$, at room temperature for $\geq 1$ $\mathrm{h}$. The slices were transferred one at a time to the recording chamber perfused with standard ACSF continuously bubbled with $95 \% \mathrm{O}_{2}$ and $5 \% \mathrm{CO}_{2}$ at $30-32^{\circ} \mathrm{C}$. Whole-cell patch-clamp recordings were made from VTA dopamine neurons visualized with an Olympus BX61W1 microscope (equipped with an mCherry filter) using infrared video microscopy and differential interference contrast optics. VTA dopaminergic neurons were identified by mCherry fluorescence. Patch electrodes were pulled from borosilicate glass capillaries; they had a resistance of 3-5 $\mathrm{M} \Omega$ when filled with intracellular solutions. Internal solution contained the following (in $\mathrm{mm}$ ): $140 \mathrm{~K}$-gluconate, $1 \mathrm{KCl}, 10 \mathrm{HEPES}, 0.5$ EGTA, 4 MgATP, $0.4 \mathrm{Na}_{2} \mathrm{GTP}, 4$ phosphocreatine, pH 7.3 with $\mathrm{KOH}$ ). Signals were amplified, filtered at $3 \mathrm{kHz}$, and digitized at $10 \mathrm{kHz}$ using an EPC-10 patch-clamp amplifier and PatchMaster v2x73 software. Series resistance was constantly monitored, and the cells were rejected from analysis if the resistance changed by $>20 \%$. No series resistance compensation was used. Resting membrane potential was measured in bridge mode $(I=0)$ immediately after obtaining whole-cell access. The basic electrophysiological properties of the cells were determined from the voltage responses to a series of hyperpolarizing and depolarizing square current pulses. Input resistance was determined by the slope of the linear regression line through the voltage-current curve. To determine the direct effect of $\mathrm{CNO}$, synaptic inputs onto these neurons were blocked using inhibitors of synaptic transmission [10 $\mu \mathrm{M}$ CNQX (Tocris Bioscience), $50 \mu \mathrm{M}$ APV (Tocris Bioscience), and $20 \mu \mathrm{m}$ bicuculline (Tocris Bioscience)]. CNO (kindly provided by Bryan Roth and the National Institute of Mental Health) was dissolved in ACSF at a concentration of $10 \mu \mathrm{M}$ and was applied to the bath through perfusion. This dose of CNO was chosen based on previous studies (Krashes et al., 2011; Robinson et al., 2014). After 10 min baseline recording, $\mathrm{CNO}$ was applied for 5-7 min and recordings were continued during and 10-20 min after the $\mathrm{CNO}$ washout period. Passive and active membrane properties were analyzed with Clampfit 10 (Axon Instrument) and Mini Analysis (Synaptosoft; RRID: SCR_014441) software.

\section{Results}

DREADD expression was limited to VTA dopamine neurons

Analysis of hM4D/mCherry following the completion of behavioral studies demonstrated that hM4D/mCherry expression was present throughout the VTA (Fig. $1 A-H$ ), but not observed in the substantia nigra (Fig. $1 I-K)$. There was limited variability in the spread of hM4D/mCherry among animals and all animals had mCherry immunoreactivity throughout the rostral-caudal extent of the VTA (from -4.56 to $-6.00 \mathrm{~mm}$ from bregma; Fig. $1 \mathrm{~N}$ ). In addition, mCherry expression extended rostrally in 36\% of animals (all groups) to $-4.36 \mathrm{~mm}$ from bregma and thus encompassed a portion of the posterior hypothalamus and extended caudally in $43 \%$ of animals (all groups) to $-6.72 \mathrm{~mm}$ from bregma. DREADD expression was also seen throughout the medial-lateral extent of the VTA (Fig. $1 B$ ). In the medial subregions of the VTA, hM4D/mCherry expression was observed in $90-100 \%$ of animals in the ventral IF (Fig. $1 B-E$ ), dorsal RLi, and CLi. In the lateral subdivisions of the VTA, hM4D/mCherry was expressed in $89-100 \%$ of animals in the rostral, middle, and caudal PBP and the ventral paranigral nucleus (Fig. $1 B, F-H$ ). Six animals (distributed among the groups) had primarily unilateral spread of the DREADD, but these animals did not differ significantly from their respective groups in any outcome measures, and were included in analyses.

Within the VTA, hM4D/mCherry was expressed in 92\% of TH-immunoreactive cells with similar coexpression in medial $(91 \pm 1.1 \%)$ and lateral $(93 \pm 1.3 \%)$ subregions of the VTA. hM4D/mCherry expression was specific to TH cells and was not observed in non-TH cells in VTA or other brain areas. Thus, $\mathrm{hM} 4 \mathrm{D} / \mathrm{mCherry}$ was restricted to TH cells in the VTA and expressed in a large majority of VTA cells.

\section{Inhibition of VTA dopamine neurons did not affect sexual behavior}

VTA dopamine neuron inhibition did not affect any parameter of sexual behavior during the 5 consecutive days of mating, as CNOtreated groups did not differ significantly from saline-treated groups in the initiation or expression of mating behavior (Fig. 2; Tables 1, 2). Moreover, both CNO-injected and saline-injected groups displayed experience-induced facilitation of sexual behavior (Fig. $2 A, B$ ). A significant effect of sexual experience (i.e., mating session), but not of $\mathrm{CNO}$, was observed for numbers of anogenital investigations $\left(F_{(1,29)}=7.1, p=0.021\right)$, mount laten- 

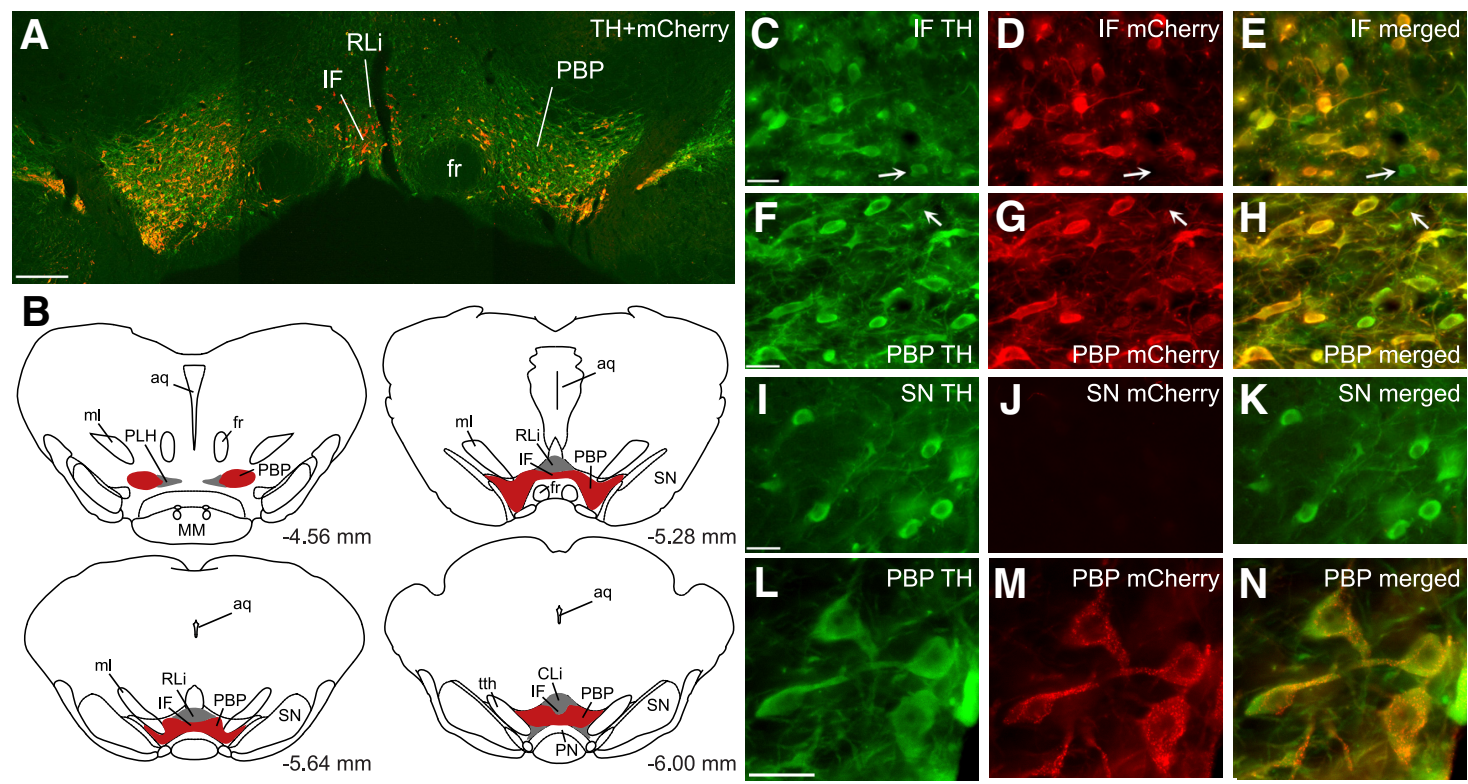

Figure 1. DREADD expression in VTA dopamine cells. $\boldsymbol{A}$, Representative image of TH (green) and mCherry (red) expression in the VTA. Scale bar, $200 \mu \mathrm{m} . \boldsymbol{B}$, Four line drawings of coronal sections indicating the representative spread of $\mathrm{mCherry}$ expression through the rostral $(-4.56 \mathrm{~mm}$ from bregma), middle $(-5.28 \mathrm{and}-5.64 \mathrm{~mm}$ from bregma) and caudal ( $-6.00 \mathrm{~mm}$ from bregma) subregions of the VTA in all (red) and the majority (gray) of animals. $\boldsymbol{C}-\boldsymbol{K}$, Representative images of $\mathrm{TH}(\boldsymbol{C}, \boldsymbol{F}, \boldsymbol{I})$, mCherry $(\boldsymbol{D}, \boldsymbol{G}, \boldsymbol{J})$, and merged TH + mCherry $(\boldsymbol{E}, \boldsymbol{H}, \boldsymbol{K})$ immunoreactivity in the IF $(\boldsymbol{C}-\boldsymbol{E})$ and PBP $(\boldsymbol{F}-\boldsymbol{H})$ subregions of the VTA and in substantia nigra $(\boldsymbol{I}-\boldsymbol{K})$. Arrows illustrate an example of a VTA TH cell without detectable mCherry expression, while all other TH cells coexpress $\mathrm{mCherry}$. Scale bar, $25 \mu \mathrm{m}$. $\boldsymbol{L}-\boldsymbol{N}$, Higher magnification of representative TH $(\boldsymbol{L})$, $\mathrm{mCherry}(\boldsymbol{M})$, and merged TH + mCherry $(\boldsymbol{N})$ immunoreactivity in the PBP subregion of the VTA. Scale bar, $25 \mu \mathrm{m}$. SN, Substantia nigra; aq, cerebral aqueduct; $\mathrm{ml}$, medial lemniscus; PLH, peduncular part of lateral hypothalamus; fr, fasciculus retroflexus; MM, mammillary nuclei; tth, trigeminothalamic tract.
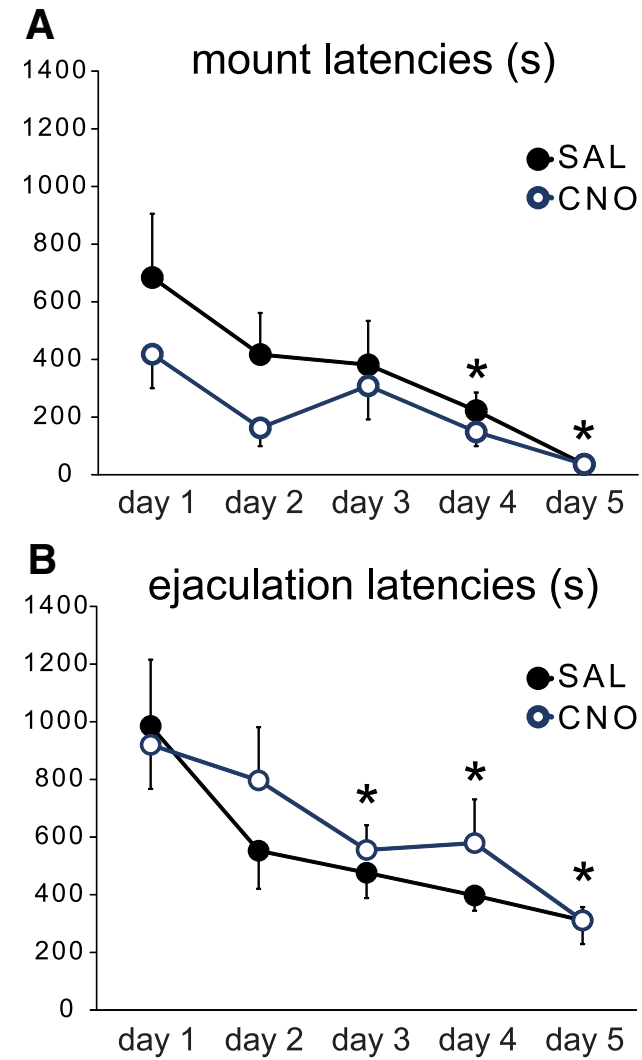

Figure 2. CNO did not affect sexual behavior during acquisition of sexual experience. $\boldsymbol{A}, \boldsymbol{B}$, Quantitative analysis of latencies (in seconds) to mount $(\boldsymbol{A})$ and ejaculation $(\boldsymbol{B})$ during 5 consecutive days of sexual behavior in saline-pretreated (SAL; black line, closed markers; $n=10$ ) and CNO-pretreated (blue line, open markers; $n=11$ ) $T H$ :: Cre transgenic rats expressing $G_{i}$ DREADD in VTA TH cells. Data represent mean \pm SEM *, Significant difference compared with day 1 of both groups combined.
Table 1. Sexual behavior parameters during 5 consecutive days of mating ${ }^{a}$

\begin{tabular}{|c|c|c|c|c|c|}
\hline Group & Day 1 & Day 2 & Day 3 & Day 4 & Day 5 \\
\hline \multicolumn{6}{|c|}{ Intromission latency } \\
\hline Saline & $716 \pm 236 s$ & $440 \pm 161 \mathrm{~s}$ & $842 \pm 310 s$ & $365 \pm 162 s$ & $42 \pm 12 s^{b}$ \\
\hline CNO & $434 \pm 117 s$ & $175 \pm 64 s$ & $315 \pm 115 s$ & $154 \pm 49 s$ & $42 \pm 13 s^{b}$ \\
\hline \multicolumn{6}{|c|}{$\begin{array}{l}\text { Copulation efficiency } \\
\qquad \text { [intromissions/ } \\
\text { (mounts }+ \\
\text { intromissions) }]\end{array}$} \\
\hline Saline & $0.8 \pm 0.1$ & $0.5 \pm 0.1$ & $0.6 \pm 0.1$ & $0.6 \pm 0.0$ & $0.7 \pm 0.0$ \\
\hline CNO & $0.6 \pm 0.0$ & $0.7 \pm 0.1$ & $0.6 \pm 0.1$ & $0.6 \pm 0.0$ & $0.7 \pm 0.1$ \\
\hline \multicolumn{6}{|c|}{ Mounts } \\
\hline Saline & 70 & 80 & 90 & 90 & 91 \\
\hline CNO & 91 & 91 & 73 & 100 & 91 \\
\hline \multicolumn{6}{|c|}{$\begin{array}{l}\text { Intromissions } \\
\qquad \text { (\% of males) }\end{array}$} \\
\hline Saline & 90 & 80 & 100 & 90 & 100 \\
\hline CNO & 91 & 100 & 73 & 100 & 100 \\
\hline \multicolumn{6}{|c|}{$\begin{array}{l}\text { Ejaculations } \\
\qquad \text { (\% of males) }\end{array}$} \\
\hline Saline & 70 & 80 & 90 & 90 & 100 \\
\hline CNO & 64 & 91 & 73 & 100 & 100 \\
\hline
\end{tabular}

${ }^{a} \mathrm{CNO}$ did not affect sexual behavior during acquisition of sexual experience. Quantitative analysis of intromission latencies (in seconds), copulation efficiency, percentages of males that display mounts, intromissions, and ejaculations, during 5 consecutive days of sexual behavior in saline-pretreated $(n=10)$ and CNO-pretreated $(n=11)$ TH::Cre transgenic rats expressing $\mathrm{G}_{\mathrm{i}}$ DREADD in VTA TH cells. Data represent mean \pm SEM.

${ }^{b}$ Significant difference compared to day 1 .

cies $\left(F_{(6,108)}=10.9, p<0.001\right)$, intromission latencies $\left(F_{(6,108)}=\right.$ 8.5, $p<0.001)$, and ejaculation latencies $\left(F_{(6,98)}=6.0, p<\right.$ 0.001). Post hoc analyses showed decreased latencies to ejaculation on days 3, 4, and 5, mount on days 4 and 5, and intromission on day 5 , compared with the first day of mating. This decrease in latencies is indicative of experience-induced facilitation of mating in both groups (all p's $<0.001$ ). There were no effects of 
Table 2. Effects of $\mathrm{CNO}$ on anogenital investigation ${ }^{a}$

\begin{tabular}{lll}
\hline Group & Day 1 & Day 5 \\
\hline $\begin{array}{l}\text { Numbers } \\
\text { Saline }\end{array}$ & $7.33 \pm 1.26$ & $3.17 \pm 1.85^{b}$ \\
CN0 & $6.00 \pm 0.55$ & $4.22 \pm 1.18^{b}$ \\
Latencies & & \\
Saline & $14.33 \pm 3.70 \mathrm{~s}$ & $17.25 \pm 8.72 \mathrm{~s}$ \\
CNO & $23.50 \pm 1.26 \mathrm{~s}$ & $12.71 \pm 3.88 \mathrm{~s}$ \\
\% Males & & \\
Saline & 100.00 & 50.00 \\
CNO & 100.00 & 77.78 \\
\hline
\end{tabular}

${ }^{a} \mathrm{CNO}$ did not affect anogenital investigations during acquisition of sexual experience. Quantitative analysis of numbers of anogenital investigations, latencies (seconds) to first anogenital investigation, and percentages of males that display anogenital investigations, during the first 2 min of day 1 and day 5 of 5 consecutive days of sexual behavior in saline-treated ( $n=6$ ) and CNO-treated $(n=9)$ TH:: Cre transgenic rats expressing G. DREADD in VTA TH cells. Data represent mean \pm SEM.

${ }^{b}$ Significant difference compared to day 1 . No significant differences between saline and CNO groups were detected.

$\mathrm{CNO}$, except for a main effect of $\mathrm{CNO}$ on intromission latencies $\left(F_{(1,108)}=4.7, p=0.043\right)$, but no group differences were detected in any post hoc comparisons. The approach behavior to the female was also unaffected by $\mathrm{CNO}$, and both groups showed a lower percentage of males displaying anogenital investigations and decreased numbers of anogenital investigations with sexual experience on day 5 compared with day $1(p=0.020)$. Finally, mating behavior in saline-injected males appeared similar to that observed in males without viral vectors in previous studies (Balfour et al., 2004; Pitchers et al., 2010b, 2013, 2014; Beloate et al., 2016), suggesting that neither expression of DREADD in VTA dopamine neurons or the use of transgenic TH::Cre rats had an impact on the initiation and expression of sexual behavior or experienceinduced facilitation. Together, these results indicate that activation of VTA dopamine neurons is not essential for the initiation or expression of male sexual behavior, or for the facilitation of sexual behavior following acquisition of mating experience.

\section{Validation of inhibition of VTA dopamine neurons during mating}

Next, using cFos as the neural activation marker, it was verified that $\mathrm{CNO}$ administration did indeed block VTA dopamine cell activation during sexual behavior (Fig. 3). There were statistically significant main effects of mating behavior on numbers of cFos/TH dual-labeled cells in the IF $\left(F_{(1,28)}=13.6, p<0.001\right)$, the $\operatorname{CLi}\left(F_{(1,28)}=10.9, p=0.003\right)$, and the middle PBP $\left(F_{(1,28)}=\right.$ 9.0, $p<0.001)$, but not in the RLi, the rostral PBP, or the caudal $\mathrm{PBP}$. In addition, there were interaction effects of mating and $\mathrm{CNO}$ on numbers of cFos/TH dual-labeled cells in the IF $\left(F_{(1,28)}\right.$ $=5.2, p=0.031)$ and the middle $\operatorname{PBP}\left(F_{(1,28)}=9.0, p<0.001\right)$, but not in the CLi, and an effect of CNO in the middle PBP $\left(F_{(1,28)}\right.$ $=9.0, p=0.007)$. Similar effects were also observed on the percentages of TH cells that coexpressed cFos: main effects of mating in the $\operatorname{IF}\left(F_{(1,28)}=12.2, p=0.002\right), \operatorname{CLi}\left(F_{(1,28)}=6.9, p=0.014\right)$, and caudal PBP $\left(F_{(1,28)}=4.4, p=0.044\right)$; and a trend in the middle $\operatorname{PBP}\left(F_{(1,28)}=3.7, p=0.064\right)$. Interactions between mating and $\mathrm{CNO}$ were found for the $\operatorname{IF}\left(F_{(1,28)}=5.2, p=0.031\right)$ and middle PBP $\left(F_{(1,28)}=11.6, p=0.002\right)$, with a main effect of CNO in the middle $\operatorname{PBP}\left(F_{(1,28)}=9.4, p=0.005\right)$. Thus, the strongest effects of mating and CNO were noted in the IF and the middle PBP. Overall, the finding that mating activated fewer cells in the lateral and caudal VTA subregions agrees with our previous finding (Balfour et al., 2004). It is important to note that there were no differences in total numbers of TH-immunoreactive cells between groups in any of the VTA subregions, suggesting that re- peated CNO administration and dopamine cell inactivation did not cause major damage or changes to TH cells (Table 3 ).

Post hoc analyses in the IF and middle PBP showed that mating increased cFos expression in $\mathrm{TH}$ cells in saline-treated mating males compared with nonmating males (all p's $<0.001$ ). In contrast, mating did not increase cFos in TH cells in CNO-treated mated males and numbers and percentages of dual-labeled cFos/TH cells in mated CNO-treated males were significantly lower compared with saline-treated mated animals [number of cFos/TH+ cells: IF $(p=0.014)$, middle PBP $(p<0.001)$; percentage of TH/cFos cells: IF $(p=0.008)$, middle PBP $(p<$ $0.001)]$, and did not differ from $\mathrm{CNO}$-treated nonmating control males (Fig. 3G-J). In the CLi, CNO-mated males did not show significantly increased cFos in $\mathrm{TH}$ cells compared with CNOtreated nonmating controls (Fig. 3G,I). CNO itself had no effect on cFos in nonmating control animals, and cFos in TH cells did not differ from saline-treated nonmating controls (Fig. 3G-J).

Finally, there were also significant effects of mating, $\mathrm{CNO}$, and interactions in the IF, CLi, and rostral PBP on cFos expression in TH-negative neurons (mating: IF, $F_{(1,29)}=6.5, p=0.017 ; \mathrm{CLi}$, $F_{(1,28)}=27.0, p<0.001$; rostral PBP, $F_{(1,28)}=12.1, p=0.002$; CNO: CLi, $F_{(1,28)}=1.4, p=0.004$; interaction between mating and CNO: IF, $F_{(1,28)}=9.0, p=0.006$; Fig. $\left.3 K, L\right)$. Post hoc analyses showed that mating increased $c F o$ in $\mathrm{TH}$-negative cells in saline-treated males in the IF $(p<0.001), \operatorname{CLi}(p<0.001)$, and rostral PBP $(p=0.002)$ compared with saline-treated no-mating controls. CNO significantly reduced mating-induced $c F o s$ in the IF $(p=0.002)$ and CLi $(p=0.004)$ compared with saline-treated mated controls. In the $\mathrm{CLi}$, this was a partial reduction and mating-induced $c$ Fos was significantly higher in CNO-treated mated males compared with nonmated males $(p<0.001)$. Since DREADD was not found in any non-TH cells in the VTA, the blockade of cFos activation is unlikely a direct effect of $\mathrm{CNO}$, and rather an indirect result of dopamine cell inhibition on neighboring VTA neurons.

\section{VTA dopamine cell inhibition did not affect mating-induced cFos in VTA projection areas}

In contrast to the effects of VTA dopamine cell inactivation on mating-induced cFos in the VTA, mating-induced cFos in VTA projection areas remained unaffected by $\mathrm{CNO}$ administration. There was a significant main effect of mating behavior on cFos expression in the NAc (core, $F_{(1,29)}=13.9, p<0.001$; shell, $\left.F_{(1,29)}=15.3, p<0.001\right), \operatorname{mPFC}\left(\mathrm{ACA}, F_{(1,28)}=12.2, p=0.002\right)$, $\operatorname{PL}\left(F_{(1,28)}=4.4, p<0.001\right), \operatorname{IL}\left(F_{(1,28)}=9.1, p<0.001\right)$, and BLA $\left(F_{(1,29)}=29.7, p<0.001\right)$, but no effects of CNO treatment or interactions were noted (Fig. 4). Mating increased cFos immunoreactivity in NAc core $(p<0.001)$, shell $(p<0.001)$, BLA $(p<$ $0.001)$, ACA $(p=0.002), \operatorname{PL}(p=0.046)$, and IL $(p=0.005)$ compared with the nonmating groups.

\section{In vitro validation of chemogenetic inhibition of VTA dopamine neurons}

To confirm inhibition of dopamine neurons upon CNO application, targeted whole-cell current-clamp recordings were made from hM4D/mCherry-expressing dopamine neurons in VTA slices prepared from $T H::$ Cre rats with hM4D expression in a separate set of male rats. Similar to the distribution in the behavioral studies, mCherry-expressing neurons were located in both lateral and medial regions of the anterior through posterior VTA. To determine the direct effect of $\mathrm{CNO}$, synaptic inputs onto these neurons were blocked using inhibitors of synaptic transmission (10 $\mu \mathrm{M}$ CNQX, $50 \mu \mathrm{M}$ APV, and $20 \mu \mathrm{m}$ bicuculline). Bath appli- 

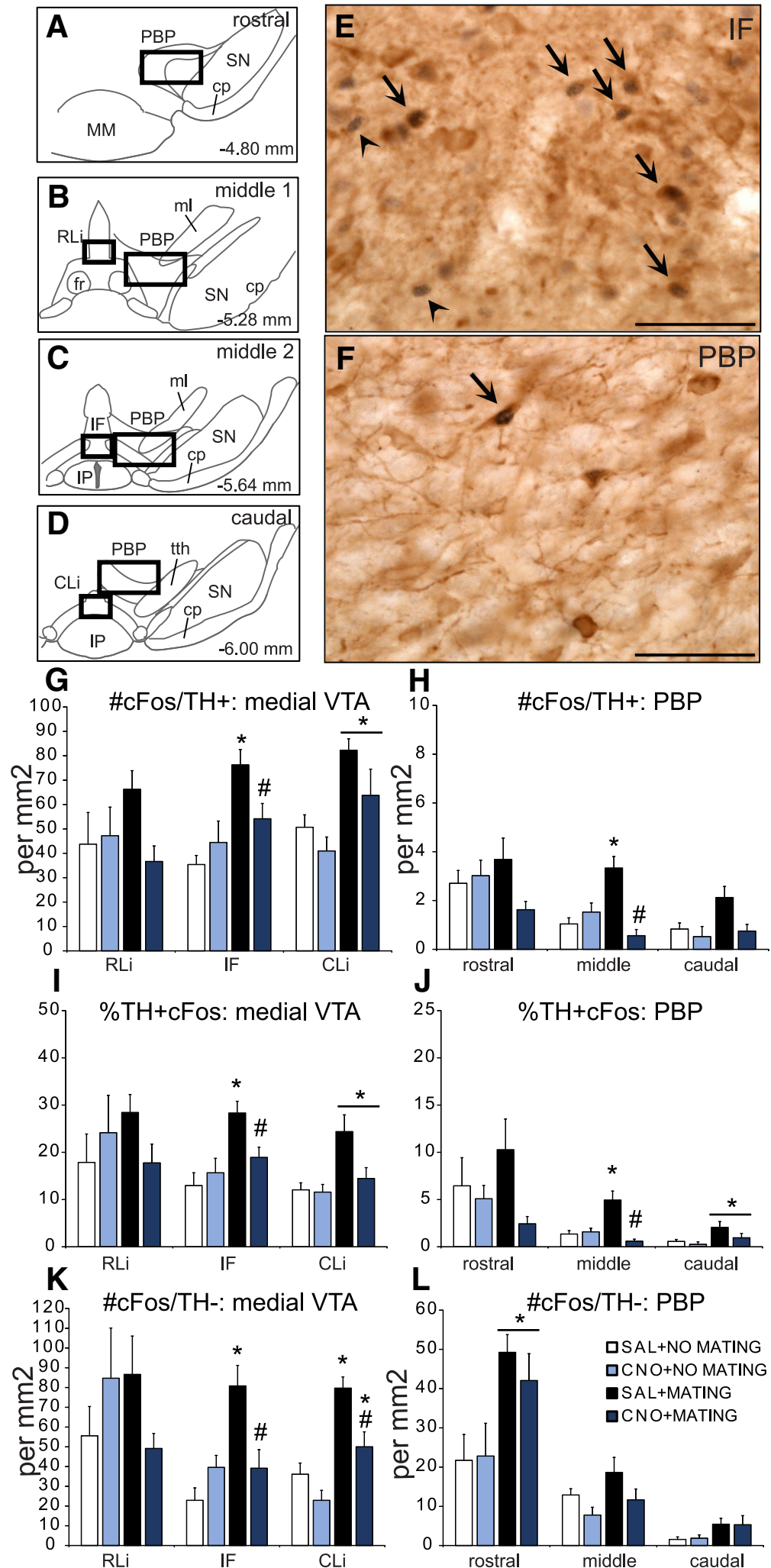

$\mathbf{L}$

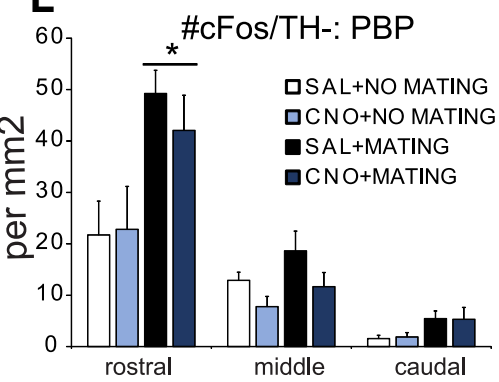

Figure 3. CNO blocked mating-induced CFos in VTA dopamine cells. $\boldsymbol{A}-\boldsymbol{D}$, Four representative rostral-caudal coronal VTA sections ( $-4.80,-5.28,-5.64,-6.00 \mathrm{~mm}$ from bregma), with boxes indicating the areas of analysis (IF, $200 \times 600 \mu \mathrm{m}$; PBP, $1000 \times 800 \mu \mathrm{m}) . \boldsymbol{E}, \boldsymbol{F}$, Representative images of cells immunopositive for cFos and TH (cFos/TH+; arrows) or cFos only (cFos/ TH - ; arrowhead) cells in the IF (E) and PBP $(\boldsymbol{F})$ subregions of the VTA. Scale bar, $50 \mu \mathrm{m}$. MM, Mammillary nuclei; SN, Substantia nigra; $c p$, cerebral peduncle; fr, fasciculus retroflexus; $\mathrm{ml}$, medial lemniscus; $\mathbb{I P}$, interpeduncular nucleus; th, trigeminothalamic tract. $\mathbf{G}-\boldsymbol{L}$, Quantitative analysis of the number of $\mathrm{cFos} / \mathrm{TH}+$ cells (per $\mathrm{mm}^{2} ; \boldsymbol{G}, \boldsymbol{H}$ ), percentage of TH cells that are also cFospositive $(\boldsymbol{I}, \boldsymbol{J})$, and number of cFos/TH - cells (per $\left.\mathrm{mm}^{2}\right)$ in rostral-middle-caudal levels $(\boldsymbol{K}, \boldsymbol{L})$ through the medial $(\boldsymbol{G}, \boldsymbol{I}, \boldsymbol{K})$ and lateral $(\boldsymbol{H}, \boldsymbol{J}, \boldsymbol{L})$ VTA subregions. Groups: saline + no mating $(S A L+N 0$ MATING), white bars, $n=6 ;$ CNO + no mating (CNO + NO MATING), light blue bars, $n=6$; saline + mating (SAL+MATING), black bars, $n=10 ;$ CNO + mating (CNO + MATING), dark blue cation of CNO $(10 \mu \mathrm{M})$ hyperpolarized the membrane potential by $6.2 \pm 0.5 \mathrm{mV}$ $(p<0.0001)$ and reduced the input resistance $(p=0.001)$ of hM4D-expressing VTA dopamine neurons compared with the baseline condition (Fig. 5A-C). Furthermore, $\mathrm{CNO}$ decreased the firing rate of spontaneous action potentials from $1.64 \pm 0.3 \mathrm{~Hz}$ to $0.4 \pm 0.2 \mathrm{~Hz}(p=0.007$; Fig. $5 D)$ and the number of evoked action potentials in hM4D-expressing neurons (Fig. 5A, sample trace). Effects of $\mathrm{CNO}$ on dopamine neurons were reversible following $\mathrm{CNO}$ washout. CNO did not affect the membrane potential of non-hM4D/ mCherry-expressing neurons in the VTA. Together, these results show that CNOactivation of hM4D reduced the excitability of VTA dopamine neurons.

\section{VTA dopamine cell inhibition during sex experience prevented cross- sensitization of amphetamine CPP} Results thus far have demonstrated that VTA dopamine cell activation is not essential for the initiation, expression, and facilitation of sexual behavior. Next, we tested the hypothesis that VTA dopamine cell activation during the acquisition of sexual experience is essential for the subsequent development of cross-sensitization of amphetamine reward-seeking behavior. First, sexually naive animals did not form an amphetamine CPP, and CNO-pretreated naive males did not differ from vehicle-treated naive males; hence vehicle-pretreated and $\mathrm{CNO}$-pretreated naive groups were combined for analyses. However, CNO administration during sexual experience did affect cross-sensitization of amphetamine CPP (Fig. 6A). Sexual experience in vehiclepretreated controls significantly increased amphetamine CPP compared with sexually naive controls $(H=9.041, p=0.011)$, thereby replicating previously published observations in wild-type Sprague Dawley males (Pitchers et al., 2010a,b, 2013, 2014; Beloate et al., 2016). Moreover, in support of our hypothesis, $\mathrm{CNO}$ pretreatment prevented the effects of sexual experience on amphetamine CPP, as the CNO sexually experienced males were significantly lower than vehicle-pretreated sexually experienced males and did not significantly differ from naive controls $(p<0.05)$.

\section{$\leftarrow$}

bars, $n=10$. Data represent mean \pm SEM. * with line, Significant difference, compared with no-mating control groups. *, Significant difference compared with the saline + nomating control group.\#, Significant difference compared with saline + mating group. 
Table 3. TH immunoreactivity in the VTA ${ }^{a}$

\begin{tabular}{|c|c|c|c|c|c|c|}
\hline \multirow[b]{2}{*}{ Group } & \multirow[b]{2}{*}{ RLi } & \multirow[b]{2}{*}{ IF } & \multirow[b]{2}{*}{ Cli } & \multicolumn{3}{|l|}{ PBP } \\
\hline & & & & Rostral & Middle & Caudal \\
\hline Saline + no mating & $34 \pm 7$ & $38 \pm 6$ & $53 \pm 7$ & $55 \pm 12$ & $67 \pm 9$ & $122 \pm 13$ \\
\hline Saline + mating & $30 \pm 3$ & $34 \pm 2$ & $46 \pm 4$ & $52 \pm 10$ & $67 \pm 13$ & $109 \pm 15$ \\
\hline $\mathrm{CNO}+$ mating & $29 \pm 4$ & $35 \pm 3$ & $52 \pm 3$ & $62 \pm 9$ & $68 \pm 10$ & $101 \pm 9$ \\
\hline
\end{tabular}

${ }^{a} \mathrm{CNO}$ did not affect TH immunoreactivity in the VTA. Quantitative analysis of numbers of TH-positive cells in the RLi, IF, CLi, and rostral, middle, and caudal VTA subregions. Data represent mean \pm SEM.

VTA dopamine cell inhibition during sex experience prevented $\Delta$ FosB expression in VTA projection areas VTA dopamine cell inactivation during sexual experience also blocked induction of $\Delta$ FosB in areas that receive dopaminergic input from the VTA (Fig. 6B-G). There were significant main effects of both sexual experience and $\mathrm{CNO}$, and significant interactions between sexual experience and $\mathrm{CNO}$ treatment in the NAc, mPFC, and BLA (NAc: sex experience: core, $F_{(1,27)}=9.4, p=0.005$; shell, $F_{(1,27)}$ $=9.3, p=0.005$; CNO: shell, $F_{(1,27)}=6.1$, $p=0.020$; interaction: core, $F_{(1,27)}=5.2$, $p=0.030$; shell, $F_{(1,27)}=12.9, p=0.001$; subregions of the $\mathrm{MPFC}$ : sex experience: ACA, $F_{(1,25)}=15.4, p<0.001 ;$ PL, $F_{(1,25)}=10.4, p=0.003 ; \mathrm{IL}, F_{(1,25)}=14.2$, $p<0.001$; CNO: ACA, $F_{(1,25)}=12.6, p<$ 0.001 ; PL, $F_{(1,25)}=14.4, p<0.001$; IL, $F_{(1,25)}=30.4, p<0.001$; interaction: ACA, $F_{(1,25)}=11.3, p=0.003 ; \mathrm{PL}$, $F_{(1,25)}=11.8, p=0.002 ; \mathrm{IL}, F_{(1,25)}=25.6$, $p<0.001$; BLA: sex experience, $F_{(1,25)}=$ 47.7, $p<0.001 ; \mathrm{CNO}, F_{(1,25)}=5.1, p=$ 0.033). In these areas, sexual experience induced $\Delta$ FosB in vehicle-pretreated males, replicating previous findings in Sprague Dawley males (Pitchers et al., 2010b, 2014; Beloate et al., 2016) as salineinjected sexually experienced rats had increased $\Delta$ FosB expression in the NAc core and shell $(p<0.001)$; in the ACA, PL, and IL subregions (all $p$ 's $<0.001$ ) of the mPFC; and in the BLA ( $p=0.015)$, compared with saline-injected sexually naive controls (Fig. 6F, G). However, CNO significantly blocked the effect of sexual experience in all areas (NAc and mPFC, $p<0.001$; BLA, $p=0.015$ ) compared with saline-treated sexually experienced males. In the $\mathrm{BLA}$, this reduction was partial, and CNO-treated sexually experienced males had higher $\Delta$ FosB expression $(p<0.001)$ compared with $\mathrm{CNO}$-treated sexually naive controls. Finally, $\mathrm{CNO}$ pretreatment during handling did not affect $\Delta$ FosB expression in these brain areas of sexually naive males.

VTA dopamine cell activation during sex experience is essential for dopamine neuron morphological changes

Along with prevention of sex experience-induced amphetamine reward cross-sensitization and $\Delta$ FosB expression, $\mathrm{CNO}$ administration during sexual experience partially attenuated experience-induced morphological changes in VTA dopamine
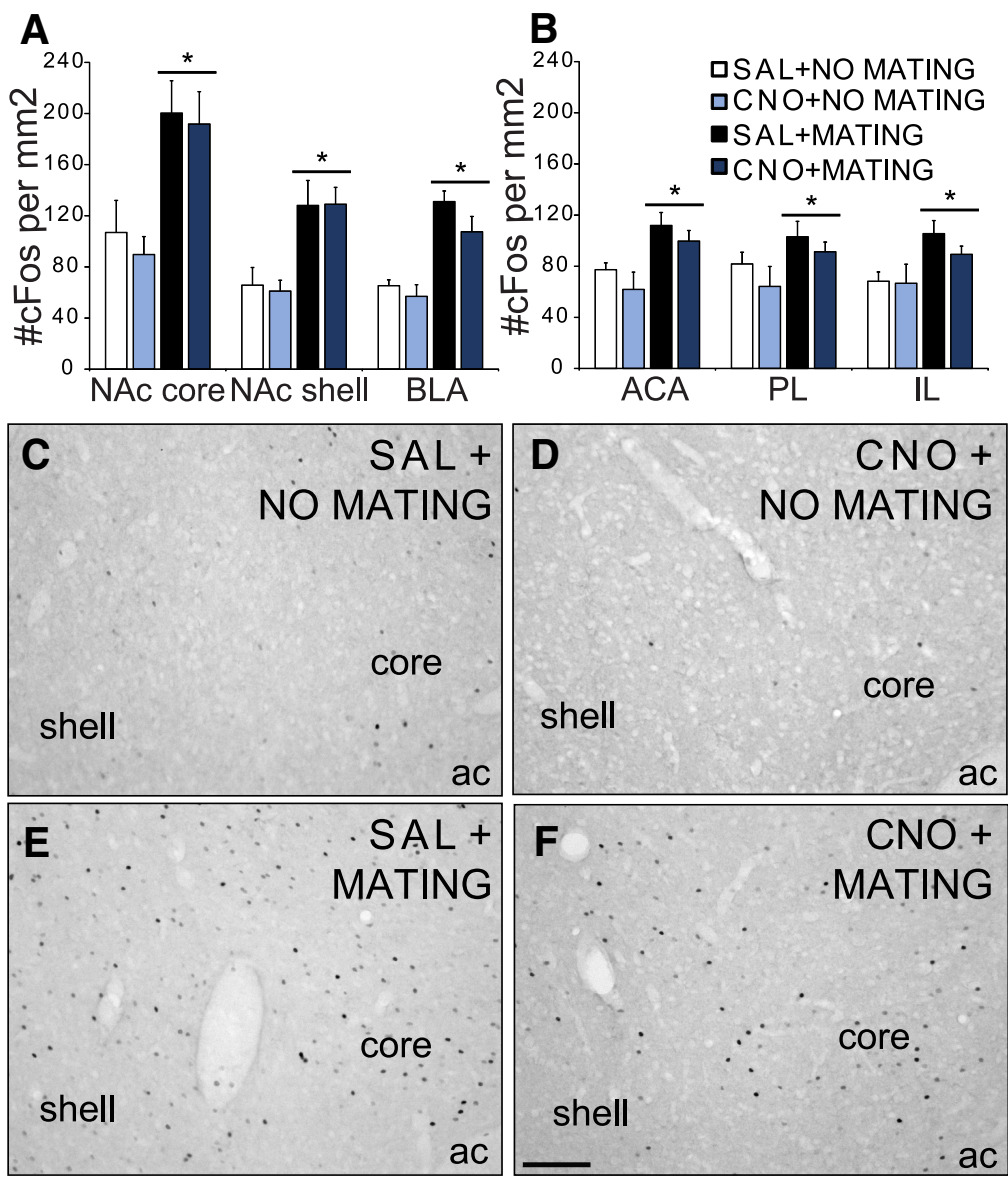

Figure 4. CNO did not affect mating-induced CFos in VTA projection areas. $A, B$, Quantitative analysis of cFos immunoreactivity $\left(\right.$ per $\left.\mathrm{mm}^{2}\right)$ in NAc core and shell, BLA $(\boldsymbol{A})$, and ACA, PL, and IL subregions of $\mathrm{mPFC}(\boldsymbol{B})$ in saline + no mating (SAL + NO MATING; white bars; $n=6$ ) or CNO + no mating (CNO+NO MATING; light blue bars; $n=6)$ and saline + mating (SAL + MATING; black tative images of cFos expression in NAc of SAL+NO MATING (C), CNO + NO MATING (D), SAL+NO MATING (E) and CNO + MATING (F) groups. Scale bar, $100 \mu \mathrm{m}$. ac, Anterior commissure. * , Significant differences to no-mating controls.

soma size (Fig. 7). First, the effects of sex experience on reduction of soma area and perimeter were confirmed as previously described for Sprague Dawley rats (Pitchers et al., 2014), and there was a significant interaction effect of sexual experience and CNO treatment on soma perimeter (sex experience, $F_{(1,25)}=28.7, p<$ 0.001 ; interaction, $\left.F_{(1,25)}=10.5, p=0.004\right)$ and area (sex experience, $F_{(1,25)}=29.0, p<0.001$; interaction, $F_{(1,25)}=5.0, p=$ $0.036)$. Post hoc analyses revealed that compared with the salineinjected naive control group, the saline-injected sexually experienced group had a significantly decreased perimeter $(92 \%$ of baseline; $p<0.001)$ and area $(87 \%$; $p<0.037)$ of VTA TH cells. Moreover, CNO administration attenuated the effects of sex experience on soma size, as cell perimeter in CNO-treated sexually experienced males did not differ from naive controls, and both cell perimeter and area were significantly larger than saline- 
A CNO $(10 \mu \mathrm{M})$
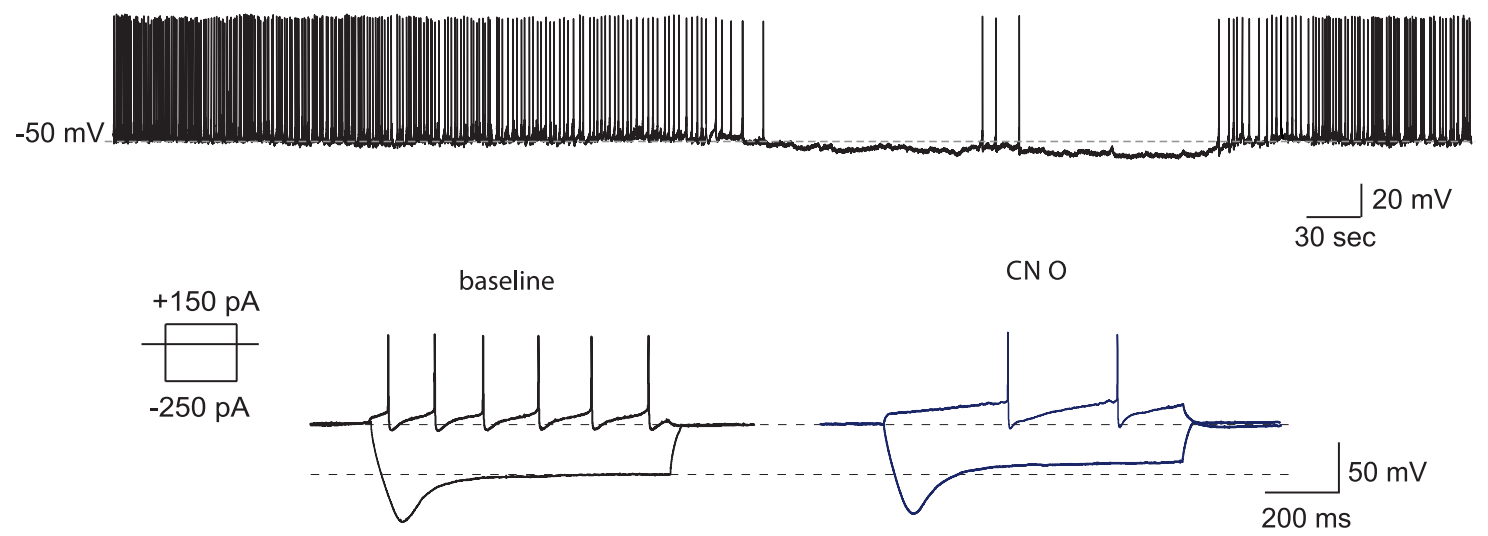

B

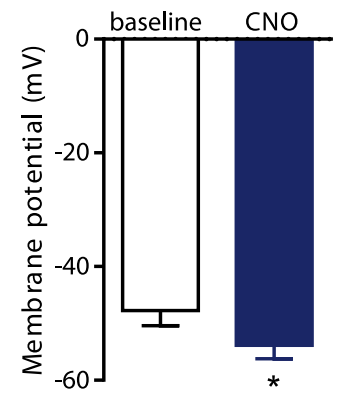

C

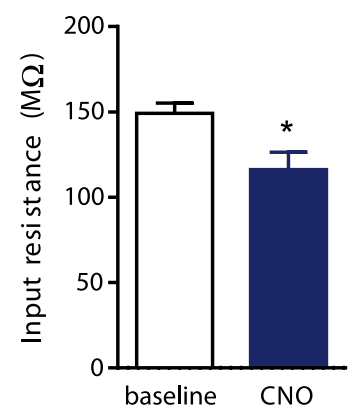

D

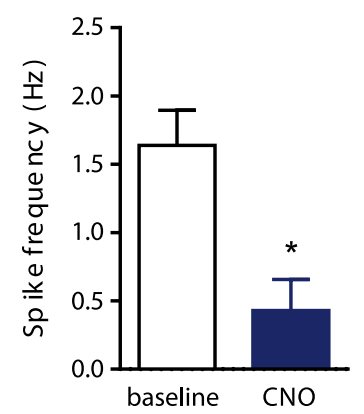

Figure 5. Inhibition of hM4D-expressing VTA dopamine neurons following CNO application. $\boldsymbol{A}$, Sample traces of spontaneous (top) and evoked action potentials (bottom) in hM4D-expressing dopamine neurons before and after CNO $(10 \mu \mathrm{m})$ application. $\boldsymbol{B}-\boldsymbol{D}$, Group data for the effect of CNO on membrane potential $(\boldsymbol{B})$, input resistance $(\boldsymbol{C})$, and firing rate of the spontaneous action potentials $(\boldsymbol{D} ; n=7)$ in hM4D-expressing VTA dopamine neurons. Data represent mean \pm SEM. ${ }^{*}$, Significant difference compared with the baseline.

treated sex experienced controls (perimeter, $p<0.001$; area, $p=$ $0.015)$. Finally, CNO treatment had no effect on TH soma size in naive controls.

\section{Discussion}

Findings from these studies showed that inactivation of VTA dopamine neurons during mating did not disrupt the initiation, performance, or short-term facilitation of sexual behavior. In contrast, chemogenetic inhibition of VTA dopamine neurons during mating prevented effects of sexual experience on neuronal plasticity in the mesolimbic pathway and on cross-sensitization of amphetamine CPP following sex abstinence. These results support the role for VTA dopamine activity in long-term rewardrelated learning. Moreover, these findings demonstrate that dopamine activation during natural reward behavior contributes to neuroplasticity mimicked by exposure to drugs of abuse, as VTA dopamine activation during mating was critical for sex experience-induced $\Delta$ FosB expression in the NAc, $\mathrm{mPFC}$, and $\mathrm{BLA}$, and the reduction of VTA dopamine soma size. In conclusion, these studies demonstrate that mesolimbic dopamine activation during natural reward exposure can influence vulnerability for drug-seeking behavior following the loss of the natural reward via neural plasticity in the NAc, PFC, BLA, and VTA.

\section{Technological considerations}

The current study used chemogenetic inhibition of VTA dopamine neurons, and hM4D/mCherry expression was confirmed to be specific to TH-immunoreactive neurons. Expression of $\mathrm{hM} 4 \mathrm{D} / \mathrm{mCherry}$ was not observed in non-TH neurons in the
VTA or other areas, ruling out nonspecific expression due to retrograde transport of the AAV (Burger et al., 2004; Aschauer et al., 2013) or Cre-recombinase expression in non-TH neurons as reported in mice (Lammel et al., 2008) but not rats (Liu et al., 2016). The TH::Cre rats have previously been validated for optogenetic manipulations of VTA dopamine cells in reward-related learning processes (Steinberg et al., 2013; Gunaydin et al., 2014; Chang et al., 2016). In agreement, here it was confirmed that $\mathrm{CNO}$ administration blocked both mating-induced cFos and excitability in VTA dopamine cells. In addition, CNO also decreased cFos expression in non- $\mathrm{TH}$ cells in the medial subregions IF and CLi, but not in the lateral subregions of the VTA. Since $\mathrm{hM} 4 \mathrm{D} / \mathrm{mCherry}$ was not expressed in non-TH cells in these regions, this may reflect reduced inputs from neighboring VTA TH cells, suggesting that dopamine neurons synapse locally on nondopamine neurons in the medial VTA.

VTA dopamine does not regulate initiation, expression, or short-term facilitation of male sexual behavior

VTA dopamine neuron inhibition did not affect approach toward the female, initiation, or performance of mating behavior, suggesting that VTA dopamine activation is not required for the control of sexual behavior per se. This further extends our previous demonstration of the lack of effects of VTA MOR blockade (Pitchers et al., 2014) and NAc D1 receptor blockade (Pitchers et al., 2013). Some effects of dopamine receptor blockade on sexual behavior have been shown using systemic administration (Pfaus and Phillips, 1991; Balthazart et al., 1997), suggesting actions in brain areas outside the mesolimbic pathway, including the me- 
dial preoptic area (Will et al., 2014). However, the lack of effects of dopamine cell inhibition on approach to the female and short-term facilitation of approach behavior are not consistent with a general role for dopamine in reward learning and incentive salience (Baik, 2013; Robinson et al., 2016; Hamid et al., 2016). Instead, these findings parallel our previous demonstration using MOR blockade in the VTA, demonstrating that the mesolimbic dopamine system is involved in the longterm memory for sexual reward, but not the initial short-term facilitation of the reward behavior (Pitchers et al., 2014). Finally, VTA dopamine neuron inhibition did not affect mating-induced cFos in the NAc, mPFC, and BLA, demonstrating that this neural activity is independent from dopamine inputs. Instead, NMDA receptor antagonism in the NAc blocks mating-induced cFos (Beloate et al., 2016), suggesting that glutamate, rather than dopamine, is the essential neurotransmitter in this brain region to induce $\mathrm{cFos}$ during sexual behavior.

\section{VTA dopamine activity mediates amphetamine cross-sensitization and expression of $\Delta$ FosB in the NAc}

In line with our hypothesis, chemogenetic inhibition of VTA dopamine activity during mating blocked sex experienceinduced increases in amphetamine CPP, even though this crosssensitization is dependent on abstinence from sexual behavior. These findings suggests that activation of dopamine neurons during sexual behavior results in long-lasting neural alterations that, in turn, influence responses to drugs of abuse. A key mediator for the role of dopamine in long-term cross-sensitization to psychostimulants is likely the transcription factor $\Delta$ FosB. Previously, we showed that sex experience-induced $\Delta$ FosB expression in the NAc is prevented by NAc infusions of D1 receptor antagonist before mating (Pitchers et al., 2013). $\Delta$ FosB expression can be induced in D1-expressing and D2-expressing neurons in the NAc, depending on the type of stimulus, and is induced by optogenetic stimulation of the VTA (Lobo et al., 2013). However, NAc $\Delta$ FosB is also prevented by local infusions of NMDA receptor antagonists during mating (Beloate et al., 2016) or can be induced by chronic stimulation of areas that provide glutamatergic inputs to the NAc, including the PFC and the amygdala (Lobo et al., 2013). Therefore, interactions between glutamate and dopamine receptor activation may contribute to $\Delta$ FosB induction. A small subpopulation of VTA dopamine neurons coexpress vGluT2 (Yamaguchi et al., 2015; Zhang et al., 2015) and potentially corelease dopamine and glutamate in the NAc (Tecuapetla et al., 2010; Zhang et al., 2015) during sexual behavior. Another question that remains is whether there are specific dopamine cell subpopulations based on afferent or efferent connections that contribute to the cross-sensitization of mating and drug reward, as has been shown for the VTA-NAc pathway in both sucrose self-administration (Boender et al., 2014) and reinforcing intracranial self-stimulation (Beier et al., 2015).

\section{VTA dopamine activity mediates natural reward-induced} expression of $\triangle$ FosB in the $\mathrm{mPFC}$

In the current study, chemogenetic inactivation of VTA dopamine activity during mating also blocked $\Delta$ FosB expression in the IL, PL, and ACA subregions of the mPFC, demonstrating an essential role of dopamine receptor activation for $\Delta \mathrm{FosB}$ induction in these areas. Such a role of dopamine for $\Delta$ FosB in areas outside the NAc has not been established, although D1R has been shown to play a role in $\Delta 9$-tetrahydrocannabinol-induced $\Delta$ FosB expression in mouse mPFC (Lazenka et al., 2014, 2015). In contrast to the extensive investigation of $\Delta$ FosB in the NAc (Nestler, 2015), less is understood regarding the functional role of $\Delta \mathrm{FosB}$ in the $\mathrm{mPFC}$ or BLA. In mice $\mathrm{mPFC}, \Delta \mathrm{FosB}$ is induced by stress partly via cholecystokinin receptor-B activation and mediates increased stress susceptibility (Lehmann and Herkenham, 2011; Vialou et al., 2014). Sexual behavior reduces stress and anxietyrelated behaviors, including decreased anxiety-like behavior (Fernández-Guasti et al., 1989; Waldherr and Neumann, 2007) and decreased fear responses (Bai et al., 2009) shortly following mating. However, the effects of a prolonged period of sexual reward abstinence on stress coping and susceptibility and potential roles for dopamine-induced $\Delta \mathrm{FosB}$ in these behaviors remain to be tested.

\section{VTA dopamine activity mediates natural reward-induced} morphological changes

In addition to dopamine-dependent neural alterations in areas downstream from the VTA, sexual experience also causes decreased soma size of VTA dopamine neurons, an effect dependent on MOR activation (Pitchers et al., 2014). Here, it is 

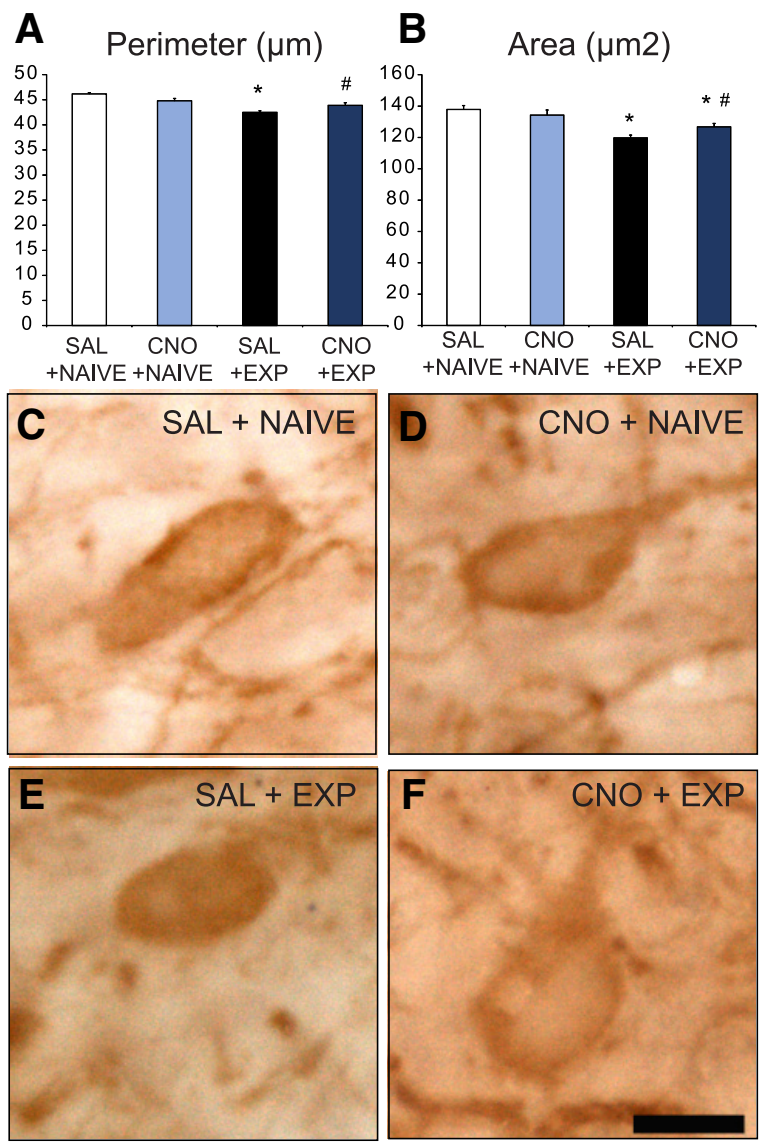

Figure 7. CNO blocked effects of sexual experience on morphology of VTA dopamine cells. $A$, $\boldsymbol{B}$, Quantitative analyses of VTA dopamine soma perimeter $(\boldsymbol{A})$ and area $(\boldsymbol{B})$ in saline + naive $($ SAL + NAIVE; white bars; $n=6)$, CNO + naive (CNO +NAIVE; light blue bars; $n=6 ; 97 \%$ perimeter, $97 \%$ area compared with SAL+NAIVE), saline + experienced (SAL + EXP; black bars; $n=9 ; 92 \%$ perimeter, $87 \%$ area compared with SAL + NAIVE), and CNO + experienced (CNO+EXP; dark blue bars; $n=10 ; 95 \%$ perimeter, $92 \%$ area compared with SAL+NAIVE) groups. Data represent mean \pm SEM. ${ }^{*}$, Significant difference from SAL+NAIVE or CNO + NAIVE. \#, Significant difference from SAL + EXP. $\boldsymbol{C}-\boldsymbol{F}$, Representative images of THimmunoreactive cells in the PBP of SAL+NAIVE $(\boldsymbol{C})$, CNO+NAIVE $(\boldsymbol{D}), \operatorname{SAL}+\operatorname{EXP}(\boldsymbol{E})$, and CNO+EXP $(\boldsymbol{F})$ groups. Scale bar, $10 \mu \mathrm{m}$.

demonstrated that this effect is also partially regulated by activity of the dopamine neuron itself. Similar alterations in soma size have been reported following chronic exposure to opiates (Mazei-Robison et al., 2011; Mazei-Robison and Nestler, 2012) and are associated with decreased dopamine trafficking and release (Mazei-Robison et al., 2011), and hyperexcitability of VTA dopamine neurons (Mazei-Robison et al., 2011), and are mediated via reduced BDNF signaling (Sklair-Tavron et al., 1996; Russo et al., 2007; Koo et al., 2012; Collo et al., 2014). Opiateinduced soma size reduction is associated with opiate reward tolerance following opiate exposure (Russo et al., 2007) and sexual experience (Pitchers et al., 2014). Even though involvement of BDNF in the effects of sex experience have not been tested, BDNF is expressed by dopamine neurons throughout the brain (Seroogy et al., 1994; Baquet et al., 2005; Graham et al., 2007) and thus potentially regulated by dopamine neuron activity. Hence, VTA dopamine inhibition during mating may partially block soma size reduction by reducing BDNF signaling. However, the dopamine soma size reduction is unlikely causally related to the cross-sensitization of amphetamine reward, as psychostimulants cause no change in soma size and increase BDNF expression (Russo et al., 2009; Fanous et al., 2011; Mazei-Robison et al.,
2014). Moreover, overexpression of BDNF in the VTA increases cross-sensitization to amphetamines (Wang et al., 2013). One possibility is that psychostimulants, opiates, and sexual behavior activate BDNF-TrKB signaling via different signaling pathways, thereby differentially regulating dopamine neuron excitability.

In conclusion, the current findings demonstrate that VTA dopamine neuron activity during sexual behavior does not prevent the motivation, expression, or short-term facilitation of this natural reward behavior. Instead, VTA dopamine regulates the cross-sensitizing effects of abstinence from sexual reward on amphetamine reward, via neural alterations, including $\Delta$ FosB expression in VTA target areas, and changes in VTA dopamine cell soma size.

These findings demonstrate that mesolimbic dopamine has a role in the interaction between natural and drug rewards and is a key mediator of changes in vulnerability for drug use after loss of natural reward.

\section{References}

Aragona BJ, Detwiler JM, Wang Z (2007) Amphetamine reward in the monogamous prairie vole. Neurosci Lett 418:190-194. CrossRef Medline

Aschauer DF, Kreuz S, Rumpel S (2013) Analysis of transduction efficiency, tropism and axonal transport of AAV serotypes 1, 2, 5, 6, 8 and 9 in the mouse brain. PLoS One 8:e76310. CrossRef Medline

Bai HY, Cao J, Liu N, Xu L, Luo JH (2009) Sexual behavior modulates contextual fear memory through dopamine D1/D5 receptors. Hippocampus 19:289-298. CrossRef Medline

Baik JH (2013) Dopamine signaling in reward-related behaviors. Front Neural Circuits 7:152. CrossRef Medline

Balfour ME, Yu L, Coolen LM (2004) Sexual behavior and sex-associated environmental cues activate the mesolimbic system in male rats. Neuropsychopharmacology 29:718-730. CrossRef Medline

Baltazar RM, Coolen LM, Webb IC (2013) Diurnal rhythms in neural activation in the mesolimbic reward system: critical role of the medial prefrontal cortex. Eur J Neurosci 38:2319-2327. CrossRef Medline

Balthazart J, Castagna C, Ball GF (1997) Differential effects of D1 and D2 dopamine-receptor agonists and antagonists on appetitive and consummatory aspects of male sexual behavior in Japanese quail. Physiol Behav 62:571-580. CrossRef Medline

Baquet ZC, Bickford PC, Jones KR (2005) Brain-derived neurotrophic factor is required for the establishment of the proper number of dopaminergic neurons in the substantia nigra pars compacta. J Neurosci 25: 6251-6259. CrossRef Medline

Beier KT, Steinberg EE, DeLoach KE, Xie S, Miyamichi K, Schwarz L, Gao XJ, Kremer EJ, Malenka RC, Luo L (2015) Circuit architecture of VTA dopamine neurons revealed by systematic input-output mapping. Cell 162: 622-634. CrossRef Medline

Beloate LN, Weems PW, Casey GR, Webb IC, Coolen LM (2016) Nucleus accumbens NMDA receptor activation regulates amphetamine crosssensitization and deltaFosB expression following sexual experience in male rats. Neuropharmacology 101:154-164. CrossRef Medline

Boender AJ, de Jong JW, Boekhoudt L, Luijendijk MC, van der Plasse G, Adan RA (2014) Combined use of the canine adenovirus-2 and DREADDtechnology to activate specific neural pathways in vivo. PLoS One 9:e95392. CrossRef Medline

Brom M, Both S, Laan E, Everaerd W, Spinhoven P (2014) The role of conditioning, learning and dopamine in sexual behavior: a narrative review of animal and human studies. Neurosci Biobehav Rev 38:38-59. CrossRef Medline

Burger C, Gorbatyuk OS, Velardo MJ, Peden CS, Williams P, Zolotukhin S, Reier PJ, Mandel RJ, Muzyczka N (2004) Recombinant AAV viral vectors pseudotyped with viral capsids from serotypes 1,2 , and 5 display differential efficiency and cell tropism after delivery to different regions of the central nervous system. Mol Ther 10:302-317. CrossRef Medline

Chang CY, Esber GR, Marrero-Garcia Y, Yau HJ, Bonci A, Schoenbaum G (2016) Brief optogenetic inhibition of dopamine neurons mimics endogenous negative reward prediction errors. Nat Neurosci 19:111-116. CrossRef Medline

Collo G, Cavalleri L, Spano P (2014) Structural plasticity in mesencephalic 
dopaminergic neurons produced by drugs of abuse: critical role of BDNF and dopamine. Front Pharmacol 5:259. CrossRef Medline

Damsma G, Pfaus JG, Wenkstern D, Phillips AG, Fibiger HC (1992) Sexual behavior increases dopamine transmission in the nucleus accumbens and striatum of male rats: comparison with novelty and locomotion. Behav Neurosci 106:181-191. CrossRef Medline

Di Chiara G (1999) Drug addiction as dopamine-dependent associative learning disorder. Eur J Pharmacol 375:13-30. CrossRef Medline

Everitt BJ, Robbins TW (2005) Neural systems of reinforcement for drug addiction: from actions to habits to compulsion. Nat Neurosci 8: 1481-1489. CrossRef Medline

Fanous S, Lacagnina MJ, Nikulina EM, Hammer RP Jr (2011) Sensitized activation of Fos and brain-derived neurotrophic factor in the medial prefrontal cortex and ventral tegmental area accompanies behavioral sensitization to amphetamine. Neuropharmacology 61:558-564. CrossRef Medline

Fernández-Guasti A, Roldán-Roldán G, Saldívar A (1989) Reduction in anxiety after ejaculation in the rat. Behav Brain Res 32:23-29. CrossRef Medline

Fields HL, Hjelmstad GO, Margolis EB, Nicola SM (2007) Ventral tegmental area neurons in learned appetitive behavior and positive reinforcement. Annu Rev Neurosci 30:289-316. CrossRef Medline

Fiorino DF, Phillips AG (1999) Facilitation of sexual behavior and enhanced dopamine efflux in the nucleus accumbens of male rats after D-amphetamine-induced behavioral sensitization. J Neurosci 19: 456-463. Medline

Frohmader KS, Pitchers KK, Balfour ME, Coolen LM (2010) Mixing pleasures: review of the effects of drugs on sex behavior in humans and animal models. Horm Behav 58:149-162. CrossRef Medline

Frohmader KS, Lehman MN, Laviolette SR, Coolen LM (2011) Concurrent exposure to methamphetamine and sexual behavior enhances subsequent drug reward and causes compulsive sexual behavior in male rats. J Neurosci 31:16473-16482. CrossRef Medline

Fu Y, Yuan Y, Halliday G, Rusznák Z, Watson C, Paxinos G (2012) A cytoarchitectonic and chemoarchitectonic analysis of the dopamine cell groups in the substantia nigra, ventral tegmental area, and retrorubral field in the mouse. Brain Struct Funct 217:591-612. CrossRef Medline

Gipson CD, Beckmann JS, El-Maraghi S, Marusich JA, Bardo MT (2011) Effect of environmental enrichment on escalation of cocaine self-administration in rats. Psychopharmacology (Berl) 214:557-566. CrossRef Medline

Graham DL, Edwards S, Bachtell RK, DiLeone RJ, Rios M, Self DW (2007) Dynamic BDNF activity in nucleus accumbens with cocaine use increases self-administration and relapse. Nat Neurosci 10:1029-1037. CrossRef Medline

Gunaydin LA, Grosenick L, Finkelstein JC, Kauvar IV, Fenno LE, Adhikari A, Lammel S, Mirzabekov JJ, Airan RD, Zalocusky KA, Tye KM, Anikeeva P, Malenka RC, Deisseroth K (2014) Natural neural projection dynamics underlying social behavior. Cell 157:1535-1551. CrossRef Medline

Hamid AA, Pettibone JR, Mabrouk OS, Hetrick VL, Schmidt R, Vander Weele CM, Kennedy RT, Aragona BJ, Berke JD (2016) Mesolimbic dopamine signals the value of work. Nat Neurosci 19:117-126. CrossRef Medline

Heilig M, Epstein DH, Nader MA, Shaham Y (2016) Time to connect: bringing social context into addiction neuroscience. Nat Rev Neurosci. Advance online publication. Retrieved Aug. 17, 2016. CrossRef Medline

Jennings JH, Ung RL, Resendez SL, Stamatakis AM, Taylor JG, Huang J, Veleta K, Kantak PA, Aita M, Shilling-Scrivo K, Ramakrishnan C, Deisseroth K, Otte S, Stuber GD (2015) Visualizing hypothalamic network dynamics for appetitive and consummatory behaviors. Cell 160:516-527. CrossRef Medline

Kalivas PW, Volkow ND (2005) The neural basis of addiction: a pathology of motivation and choice. Am J Psychiatry 162:1403-1413. CrossRef Medline

Kenny PJ (2011) Reward mechanisms in obesity: new insights and future directions. Neuron 69:664-679. CrossRef Medline

Koo JW, Mazei-Robison MS, Chaudhury D, Juarez B, LaPlant Q, Ferguson D, Feng J, Sun H, Scobie KN, Damez-Werno D, Crumiller M, Ohnishi YN, Ohnishi YH, Mouzon E, Dietz DM, Lobo MK, Neve RL, Russo SJ, Han MH, Nestler EJ (2012) BDNF is a negative modulator of morphine action. Science 338:124-128. CrossRef Medline

Koob GF, Buck CL, Cohen A, Edwards S, Park PE, Schlosburg JE, Schmeichel B,
Vendruscolo LF, Wade CL, Whitfield TW Jr, George O (2014) Addiction as a stress surfeit disorder. Neuropharmacology 76:370-382. CrossRef Medline

Krashes MJ, Koda S, Ye C, Rogan SC, Adams AC, Cusher DS, Maratos-Flier E, Roth BL, Lowell BB (2011) Rapid, reversible activation of AgRP neurons drives feeding behavior in mice. J Clin Invest 121:1424-1428. CrossRef Medline

Lammel S, Hetzel A, Häckel O, Jones I, Liss B, Roeper J (2008) Unique properties of mesoprefrontal neurons within a dual mesocorticolimbic dopamine system. Neuron 57:760-773. CrossRef Medline

Lazenka MF, Selley DE, Sim-Selley LJ (2014) DeltaFosB induction correlates inversely with $\mathrm{CB}(1)$ receptor desensitization in a brain regiondependent manner following repeated Delta(9)-THC administration. Neuropharmacology 77:224-233. CrossRef Medline

Lazenka MF, Tomarchio AJ, Lichtman AH, Greengard P, Flajolet M, Selley DE, Sim-Selley LJ (2015) Role of dopamine type 1 receptors and dopamine- and cAMP-regulated phosphoprotein Mr $32 \mathrm{kDa}$ in Delta9tetrahydrocannabinol-mediated induction of DeltaFosB in the mouse forebrain. J Pharmacol Exp Ther 354:316-327. CrossRef Medline

Lee HM, Giguere PM, Roth BL (2014) DREADDs: novel tools for drug discovery and development. Drug Discov Today 19:469-473. CrossRef Medline

Lehmann ML, Herkenham M (2011) Environmental enrichment confers stress resiliency to social defeat through an infralimbic cortex-dependent neuroanatomical pathway. J Neurosci 31:6159-6173. CrossRef Medline

Liu Y, Young KA, Curtis JT, Aragona BJ, Wang Z (2011) Social bonding decreases the rewarding properties of amphetamine through a dopamine D1 receptor-mediated mechanism. J Neurosci 31:7960-7966. CrossRef Medline

Liu Z, Brown A, Fisher D, Wu Y, Warren J, Cui X (2016) Tissue specific expression of Cre in rat tyrosine hydroxylase and dopamine active transporter-positive neurons. PLoS One 11:e0149379. CrossRef Medline

Lobo MK, Zaman S, Damez-Werno DM, Koo JW, Bagot RC, DiNieri JA, Nugent A, Finkel E, Chaudhury D, Chandra R, Riberio E, Rabkin J, Mouzon E, Cachope R, Cheer JF, Han MH, Dietz DM, Self DW, Hurd YL, Vialou $\mathrm{V}$ et al. (2013) $\Delta$ FosB induction in striatal medium spiny neuron subtypes in response to chronic pharmacological, emotional, and optogenetic stimuli. J Neurosci 33:18381-18395. CrossRef Medline

Lu L, Shepard JD, Hall FS, Shaham Y (2003) Effect of environmental stressors on opiate and psychostimulant reinforcement, reinstatement and discrimination in rats: a review. Neurosci Biobehav Rev 27:457-491. CrossRef Medline

Mazei-Robison MS, Nestler EJ (2012) Opiate-induced molecular and cellular plasticity of ventral tegmental area and locus coeruleus catecholamine neurons. Cold Spring Harb Perspect Med 2:a012070. CrossRef Medline

Mazei-Robison MS, Koo JW, Friedman AK, Lansink CS, Robison AJ, Vinish M, Krishnan V, Kim S, Siuta MA, Galli A, Niswender KD, Appasani R, Horvath MC, Neve RL, Worley PF, Snyder SH, Hurd YL, Cheer JF, Han $\mathrm{MH}$, Russo SJ et al. (2011) Role for mTOR signaling and neuronal activity in morphine-induced adaptations in ventral tegmental area dopamine neurons. Neuron 72:977-990. CrossRef Medline

Mazei-Robison MS, Appasani R, Edwards S, Wee S, Taylor SR, Picciotto MR, Koob GF, Nestler EJ (2014) Self-administration of ethanol, cocaine, or nicotine does not decrease the soma size of ventral tegmental area dopamine neurons. PLoS One 9:e95962. CrossRef Medline

Nader J, Chauvet C, Claudia C, Rawas RE, Favot L, Jaber M, Thiriet N, Solinas M (2012) Loss of environmental enrichment increases vulnerability to cocaine addiction. Neuropsychopharmacology 37:1579-1587. CrossRef Medline

Nestler EJ (2015) FosB: a transcriptional regulator of stress and antidepressant responses. Eur J Pharmacol 753:66-72. CrossRef Medline

Olsen CM (2011) Natural rewards, neuroplasticity, and non-drug addictions. Neuropharmacology 61:1109-1122. CrossRef Medline

Pandit R, Omrani A, Luijendijk MC, de Vrind VA, Van Rozen AJ, Ophuis RJ, Garner K, Kallo I, Ghanem A, Liposits Z, Conzelmann KK, Vanderschuren LJ, la Fleur SE, Adan RA (2016) Melanocortin 3 receptor signaling in midbrain dopamine neurons increases the motivation for food reward. Neuropsychopharmacology 41:2241-2251. CrossRef Medline

Perrotti LI, Hadeishi Y, Ulery PG, Barrot M, Monteggia L, Duman RS, Nestler EJ (2004) Induction of $\Delta$ FosB in reward-related brain structures after chronic stress. J Neurosci 24:10594-10602. CrossRef Medline

Perrotti LI, Weaver RR, Robison B, Renthal W, Maze I, Yazdani S, Elmore RG, Knapp DJ, Selley DE, Martin BR, Sim-Selley L, Bachtell RK, Self DW, 
Nestler EJ (2008) Distinct patterns of DeltaFosB induction in brain by drugs of abuse. Synapse 62:358-369. CrossRef Medline

Pfaus JG, Phillips AG (1991) Role of dopamine in anticipatory and consummatory aspects of sexual behavior in the male rat. Behav Neurosci 105: 727-743. CrossRef Medline

Pfaus JG, Damsma G, Nomikos GG, Wenkstern DG, Blaha CD, Phillips AG, Fibiger HC (1990) Sexual behavior enhances central dopamine transmission in the male rat. Brain Res 530:345-348. CrossRef Medline

Pitchers KK, Balfour ME, Lehman MN, Richtand NM, Yu L, Coolen LM (2010a) Neuroplasticity in the mesolimbic system induced by natural reward and subsequent reward abstinence. Biol Psychiatry 67:872-879. CrossRef Medline

Pitchers KK, Frohmader KS, Vialou V, Mouzon E, Nestler EJ, Lehman MN, Coolen LM (2010b) DeltaFosB in the nucleus accumbens is critical for reinforcing effects of sexual reward. Genes Brain Behav 9:831-840. CrossRef Medline

Pitchers KK, Vialou V, Nestler EJ, Laviolette SR, Lehman MN, Coolen LM (2013) Natural and drug rewards act on common neural plasticity mechanisms with $\Delta$ FosB as a key mediator. J Neurosci 33:3434-3442. CrossRef Medline

Pitchers KK, Coppens CM, Beloate LN, Fuller J, Van S, Frohmader KS, Laviolette SR, Lehman MN, Coolen LM (2014) Endogenous opioid-induced neuroplasticity of dopaminergic neurons in the ventral tegmental area influences natural and opiate reward. J Neurosci 34:8825-8836. CrossRef Medline

Pitchers KK, Di Sebastiano AR, Coolen LM (2016) mGluR5 activation in the nucleus accumbens is not essential for sexual behaviour or crosssensitization of amphetamine responses by sexual experience. Neuropharmacology 107:122-130. CrossRef Medline

Robinson MJ, Fischer AM, Ahuja A, Lesser EN, Maniates H (2016) Role of "wanting" and "liking" in motivating behavior: gambling, food, and drug addictions. Curr Top Behav Neurosci 27:105-136. CrossRef Medline

Robinson S, Todd TP, Pasternak AR, Luikart BW, Skelton PD, Urban DJ, Bucci DJ (2014) Chemogenetic silencing of neurons in retrosplenial cortex disrupts sensory preconditioning. J Neurosci 34:10982-10988. CrossRef Medline

Russo SJ, Bolanos CA, Theobald DE, DeCarolis NA, Renthal W, Kumar A, Winstanley CA, Renthal NE, Wiley MD, Self DW, Russell DS, Neve RL, Eisch AJ, Nestler EJ (2007) IRS2-Akt pathway in midbrain dopamine neurons regulates behavioral and cellular responses to opiates. Nat Neurosci 10:93-99. CrossRef Medline

Russo SJ, Mazei-Robison MS, Ables JL, Nestler EJ (2009) Neurotrophic factors and structural plasticity in addiction. Neuropharmacology 56 [Suppl 1]:73-82. CrossRef Medline

Schultz W (2013) Updating dopamine reward signals. Curr Opin Neurobiol 23:229-238. CrossRef Medline

Seroogy KB, Lundgren KH, Tran TM, Guthrie KM, Isackson PJ, Gall CM (1994) Dopaminergic neurons in rat ventral midbrain express brainderived neurotrophic factor and neurotrophin-4 mRNAs. J Comp Neurol 342:321-334. CrossRef Medline
Sklair-Tavron L, Shi WX, Lane SB, Harris HW, Bunney BS, Nestler EJ (1996) Chronic morphine induces visible changes in the morphology of mesolimbic dopamine neurons. Proc Natl Acad Sci U S A 93:11202-11207. CrossRef Medline

Solinas M, Thiriet N, Chauvet C, Jaber M (2010) Prevention and treatment of drug addiction by environmental enrichment. Prog Neurobiol 92: 572-592. CrossRef Medline

Stauffer WR, Lak A, Kobayashi S, Schultz W (2016) Components and characteristics of the dopamine reward utility signal. J Comp Neurol 524: 1699-1711. CrossRef Medline

Steinberg EE, Keiflin R, Boivin JR, Witten IB, Deisseroth K, Janak PH (2013) A causal link between prediction errors, dopamine neurons and learning. Nat Neurosci 16:966-973. CrossRef Medline

Tecuapetla F, Patel JC, Xenias H, English D, Tadros I, Shah F, Berlin J, Deisseroth K, Rice ME, Tepper JM, Koos T (2010) Glutamatergic signaling by mesolimbic dopamine neurons in the nucleus accumbens. J Neurosci 30:7105-7110. CrossRef Medline

Thiel KJ, Sanabria F, Pentkowski NS, Neisewander JL (2009) Anti-craving effects of environmental enrichment. Int J Neuropsychopharmacol 12: 1151-1156. CrossRef Medline

Vialou V, Bagot RC, Cahill ME, Ferguson D, Robison AJ, Dietz DM, Fallon B, Mazei-Robison M, Ku SM, Harrigan E, Winstanley CA, Joshi T, Feng J, Berton O, Nestler EJ (2014) Prefrontal cortical circuit for depressionand anxiety-related behaviors mediated by cholecystokinin: role of $\Delta$ FosB. J Neurosci 34:3878-3887. CrossRef Medline

Waldherr M, Neumann ID (2007) Centrally released oxytocin mediates mating-induced anxiolysis in male rats. Proc Natl Acad Sci U S A 104: 16681-16684. CrossRef Medline

Wang J, Fanous S, Terwilliger EF, Bass CE, Hammer RP Jr, Nikulina EM (2013) BDNF overexpression in the ventral tegmental area prolongs social defeat stress-induced cross-sensitization to amphetamine and increases DeltaFosB expression in mesocorticolimbic regions of rats. Neuropsychopharmacology 38:2286-2296. CrossRef Medline

Will RG, Hull EM, Dominguez JM (2014) Influences of dopamine and glutamate in the medial preoptic area on male sexual behavior. Pharmacol Biochem Behav 121:115-123. CrossRef Medline

Wise RA (2002) Brain reward circuitry: insights from unsensed incentives. Neuron 36:229-240. CrossRef Medline

Witten IB, Steinberg EE, Lee SY, Davidson TJ, Zalocusky KA, Brodsky M, Yizhar O, Cho SL, Gong S, Ramakrishnan C, Stuber GD, Tye KM, Janak PH, Deisseroth K (2011) Recombinase-driver rat lines: tools, techniques, and optogenetic application to dopamine-mediated reinforcement. Neuron 72:721-733. CrossRef Medline

Yamaguchi T, Qi J, Wang HL, Zhang S, Morales M (2015) Glutamatergic and dopaminergic neurons in the mouse ventral tegmental area. Eur J Neurosci 41:760-772. CrossRef Medline

Zhang S, Qi J, Li X, Wang HL, Britt JP, Hoffman AF, Bonci A, Lupica CR, Morales M (2015) Dopaminergic and glutamatergic microdomains in a subset of rodent mesoaccumbens axons. Nat Neurosci 18:386-392. CrossRef Medline 